\title{
Los nombres de Don Quijote
}

\author{
GUILLERMO FERnÁNDEZ RodRÍGUEZ-ESCALONA*
}

Hablar es elegir. Cuando habla, el locutor tiene a su disposición el amplio repertorio de medios expresivos que constituye la lengua, de los cuales escoge aquellos que mejor se avienen con sus necesidades expresivas; en sus elecciones perfila el hablante el tema del hablar y también se perfila a sí mismo, por cuanto el tomar unas u otras opciones informa acerca de cómo representa lo que representa en el discurso, es decir, se sitúa en relación con la representación efectuada. Este es el postulado básico del análisis estilístico, que me dispongo a aplicar al análisis de los distintos nombres que Cervantes otorga al personaje central de Don Quijote de la Mancha. Este asunto ha suscitado la atención de renombrados filólogos y reputados cervantistas, especialmente desde que Leo Spitzer diera a conocer su ensayo "Perspectivismo lingüístico en el Quijote", una de las primeras y más lúcidas interpretaciones de la polionomasia en la novela cervantina. Desde entonces, el tema ha estado presente, en mayor o menor medida, en los análisis de la obra, y a él se ha consagrado un buen número de trabajos dedicados a desentrañar los aspectos significativos de los nombres del caballero andante o del hidalgo del innombrado lugar manchego; las aportaciones de los más relevantes se discutirán a lo largo de estas páginas.

No obstante, la atención que se ha dedicado al problema de los nombres adolece de parcialidad. Con el término "parcialidad" quiere decirse aquí, en primer lugar, que se ha estudiado cada nombre como un todo aislado e independiente de los otros nombres del personaje y, en segundo lugar, quiere también señalarse que, con pocas excepciones, el significado de los nombres se ha 
considerado de una manera inmanente, esto es, desligado del hecho de ser un medio al servicio de la concreción de las necesidades expresivas del autor. Pero el sentido de los nombres está íntimamente relacionado con su para qué dentro del mundo representado en el texto, es decir, son elementos que se utilizan en función del tratamiento de un problema de nivel superior al de la determinación de los propios nombres. Para tratar de salvar la primera de estas limitaciones, en este trabajo se aborda el estudio de los nombres desde la consideración de que cada uno adquiere su pleno sentido en relación con todos los demás y que el sentido total reside en el conjunto más que en la suma de lo que representa cada nombre por separado; para salvar la segunda, se estudiará el sentido de los nombres de don Quijote como recurso expresivo en que se concretan distintos matices de la identidad del personaje, teniendo en cuenta que el concepto de identidad se subordina, a su vez, al problema de la verdad, auténtico tema de fondo del Quijote.

A primera vista, escapa de esta parcialidad la explicación del nombre de don Quijote como creación paródica de los nombres caballerescos ${ }^{1}$; es verdad, sustancialmente, que el nombre del caballero cervantino constituye una burla de los nombres caballerescos, pero eso no refleja todo el sentido que llega a alcanzar en la novela. En la parodia de la onomástica caballeresca está presupuesto no solo un modo de nombrar, sino también la relación existente entre esa manera de nombrar y la personalidad del caballero andante; Cervantes toma un modelo onomástico relacionado con un modo de conciencia de uno mismo y lo pone a prueba enfrentándolo a un contexto muy distinto de aquel para el que había sido ideado.

Más rigurosos son los planteamientos de Leo Spitzer y de E. C. Riley, autor de un interesante estudio sobre la relación entre nombre e identidad. Spitzer busca, tras la variedad onomástica, su auténtica función: mostrar la concepción cervantina de la vida y del arte. El análisis de la polionomasia le lleva a la idea de que Cervantes destaca "los diferentes aspectos bajo los que puede aparecer a los demás el personaje en cuestión"2; de donde deduce que Cervantes concibe la realidad como una confluencia de puntos de vista; pero, junto al oscilante imperio de la perspectiva, Spitzer intuye "la presencia de algo que no está sujeto a fluctuación" sin llegar a explicar satisfactoriamente cómo se integran lo uno y lo otro en la obra de Cervantes.

Riley, por su parte, emprende un examen de la conexión entre nombre y personalidad que le hace llegar a la conclusión de que "la identidad personal se desintegra" 3 en la maraña de variedades denominativas. La idea de identi-

1. Esta explicación ha sido admitida de manera generalizada por los cervantistas. Véanse, por ejemplo, MARTín DE RiQuer, Aproximación al Quijote, Barcelona, Salvat, 1970, y Ángel Rosenblat, La lengua del Quijote, Madrid, Gredos, 1971.

2. Leo SPITZER, "Perspectivismo lingüístico en el Quijote", en Lingüística e historia literaria,

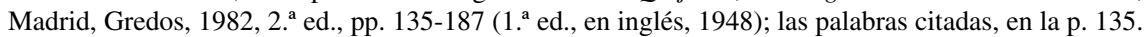

3. EdWARD C. RILEY, "Who's Who in Don Quixote? Or an Approach to the Problem of Identity", Modern Language Notes, LXXXI (1966), pp. 113-130; traducido como "Quién es quién en el Quijo- 
dad es noción resbaladiza, que oscila entre la conciencia que uno tiene de sí mismo y la imagen que de la propia identidad se proyecta hacia los demás, entre lo que tiene de hecho cultural y lo que tiene de fenómeno natural, y entre la variabilidad y la estabilidad. A nuestro modo de ver, Cervantes la concibe como conciencia plenamente autónoma, voluntariamente determinada por modelos culturales y, esencialmente, variable en el tiempo sin perder su uni$\mathrm{dad}^{4}$. Riley, que hace suya la idea perspectivista de Spitzer, parece conceder más peso a lo que en la identidad hay de determinación externa y de inmutable fenómeno natural, ideas que también están presentes en Cervantes, pero están ahí como rémora que limitan la voluntad de ser. El empeño del cura, de maese Nicolás, de Sansón Carrasco, del ama y de la sobrina es el de imponer a don Quijote el molde social de su identidad, imbuidos de la conciencia de que el auténtico ser del personaje es el de su primigenio estado de hidalgo. Riley examina la identidad de don Quijote desde esa misma perspectiva, pero la del autor es muy diferente: Cervantes muestra en el protagonista la confrontación entre la voluntad de hacerse uno mismo y la presión que el medio social ejerce contra esa voluntad. En consecuencia, no llega Riley a advertir el nexo que une los distintos nombres del personaje en un todo: la construcción de la propia identidad como un proceso que realiza una voluntad de ser y no como la suma de diversos estados de autoconciencia sucesivos y sin más relación entre ellos que tener su origen en un solo personaje. Los detalles sobre el contenido de la identidad, sobre los modelos culturales a que se ajusta y sobre su variabilidad son aspectos que irán desarrollándose al hilo del análisis de los nombres del personaje.

Así pues, partimos de que el sentido de cada uno de esos nombres está determinado por el hecho de oponerse a los otros nombres y por reflejar de una $\mathrm{u}$ otra manera la identidad del protagonista del Quijote. La incertidumbre sobre el nombre del hidalgo del primer capítulo, la fijeza de don Quijote de la Mancha (en contraste con la inestabilidad de los apelativos) y la autenticidad de Alonso Quijano en el capítulo final constituyen sucesivas etapas denominativas que emanan de cómo se percibe el personaje o cómo lo perciben otros. Esas percepciones, así como los nombres, son elementos del texto y se estructuran en relación con el universo significativo representado en el texto mismo; desde el texto y en el texto han de explicarse, sin olvidar que el texto es creación lingüística y que en la lengua se plasman convenciones culturales vigentes para sus hablantes. Por ello no está de más empezar el examen de los nombres de don Quijote por el de la consideración que se da al nombre propio en los tratados gramaticales de la época de Cervantes.

te. Aproximación al problema de la identidad" e incluido en el volumen del autor La rara invención. Estudios sobre Cervantes y su posteridad literaria, Barcelona, Crítica, 2001, p. 49.

4. Como escribe PAUL RICOEUR, "la historia de una vida se constituye por una sucesión de rectificaciones aplicadas a relatos previos", Tiempo y narración, III, El tiempo narrado, Madrid, Siglo XXI, 1996, p. 999. Véase, de este mismo autor, "La identidad narrativa", incluido en Historia y narratividad, Barcelona, Paidós, 1999, pp. 215-230. 


\section{INTRODUCCIÓN: EL NOMBRE PROPIO EN LOS SIGLOS XVI Y XVII}

"Propio nombre es aquel que conviene a uno solo", decía Nebrija, siguiendo una milenaria tradición, a fines del siglo XV. Con estas palabras se recogía en la lengua vulgar una idea, la de que el nombre propio corresponde a un ser singular, que llega hasta el presente y, formulada con matices, resonó en el Licenciado Villalón, en fray Luis de León y en Correas ${ }^{5}$. La obra de Correas, aunque posterior en poco a la de Cervantes, describe unas pautas sobre el uso de los nombres ${ }^{6}$ que eran comunes desde mucho antes de la fecha de publicación de su Arte de la lengua española castellana (1626), de modo que su testimonio no resulta ilegítimo para validar cualquier estudio sobre el nombre propio en tiempos de Cervantes.

Controvertido es el sentido que estos autores atribuyen a los nombres propios. Para fray Luis de León, el nombre constituye una imagen de las cosas, aunque muy debilitada. Se acoge fray Luis, en términos generales, a la tradición especulativa de raigambre platónica sobre la significación natural de las palabras, pero no deja de puntualizar que las prácticas culturales se rigen por principios que muy escasamente se atienen a los fundamentos teóricos de su doctrina sobre el nombre ${ }^{7}$; así, aunque postula para los nombres propios una "significación de alguna particular propiedad y de algo de lo que es propio a aquello de quien se dicen", en la práctica este sentido "natural" de los nombres está condicionado a los que adrede se imponen con este propósito ${ }^{8}$. Nebrija y Correas se desentienden del significado de los nombres propios ${ }^{9}$ y les adjudican una función meramente identificadora, como señala Correas a propósito de los patronímicos: "Pareze verisimil que se inventaron los patronimicos para distinguir los onbres mas fazilmente despues que se introduxo tomar los nonbres unos de otros, i llamarse muchos de un nonbre, como Sanchos, Pedros, Gonzalos, Xuanes, Fernandos" (p. 209).

5. "Los nombres propios significan una cosa singular o singular persona" (VILlaLón, Gramática castellana. Arte breve y compendiosa para saber hablar y escrebir en la lengua castellana congrua y deçentemente, Anvers, en casa de Guillermo Simón, 1558, pág. 14). "Hay unas palabras o nombres que se aplican a muchos, y se llaman nombres comunes, y otros que son propios de solo uno" (FRAY LUIS DE LEón, De los nombres de Cristo, en Obras castellanas completas, edición de Félix García, Madrid, Biblioteca de Autores Cristianos, 1959, 3. ${ }^{\text {a }}$ edición, pp. 398-399). "Propio i particular es el nombre de cada uno, i de cada cosa particularmente puesta, i se escrive con letra grande para maior señal" (GoNZALo CorReas, Arte de la lengua española castellana, edición y prólogo de Emilio Alarcos García, Madrid, CSIC, 1954, p. 156).

6. En concreto, nos referimos al apartado "Patronímicos i sobrenombres", incluido en el capítulo XL, "De otras particulares espezies de nombres" (edición citada, pp. 208-213).

7. Bien es verdad que el propósito de FRAY LUIS -como figura en el título de su diálogo- no es el de reflexionar sobre los antropónimos.

8. Sin embargo, como el mismo autor reconoce, "no se guarda esto siempre en las lenguas; es grande verdad" (De los nombres de Cristo, p. 399)

9. "No disputemos si los primitivos o primeros que puso Adan, i se pusieron despues en la division de las lenguas, sinificavan las naturalezas de las cosas, que seria prozeder en infinito, i no asentariamos nada" (Correas, Arte de la lengua..., p. 133). 
Los nombres de persona constan de toda una serie de elementos imprescindibles para llevar a término la identificación del individuo. Imprescindible es el nombre de pila, aunque puede darse el caso de que a varias personas se les imponga el mismo, con lo cual su función identificadora queda muy atenuada, de modo que se hace necesario añadir otras determinaciones. La más importante de ellas es el sobrenombre (connombre en Nebrija), determinación postpuesta que "es el nombre que se añade al propio i es comun a todos los de un linaxe", sigue diciendo Correas. El sobrenombre es relativamente estable y, por lo general, se transmite de generación en generación, pero no es en absoluto fijo ni obligatorio; Correas habla de cambios motivados por variados criterios: "A vezes trocando i tomando el que tienen por mas noble o es mas a su gusto, i a vezes alguno de los aghuelos, o tio, por particulares rrespectos de interes, amor, favor i adulazion" 10 .

$\mathrm{Al}$ de pila pueden anteponerse nombres honoríficos (prenombres en $\mathrm{Ne}$ brija: san, fray, frey), como el tan traído y llevado don. Covarrubias dice de este tratamiento: "Es título honorífico, que se da al caballero y noble y al constituido en dignidad"11, y poco más adelante agrega: "Muchas casas de señores han rehusado el don, y no se le ponen; y por estos pocos que le dejan le han tomado muchos, que no se les debe". La punzante observación de Covarrubias testimonia, por un lado, que el tratamiento está reservado a personas de cierta calidad y, por otro, que esas restricciones son inoperantes.

Sobrenombre y prenombre están relacionados con el ser social del individuo al que identifican, pero no todos los añadidos que puede llevar un nombre están condicionados por la naturaleza social de la nominación. A los elementos enumerados añade Nebrija otro, el renombre, que "es aquel que para más determinar el nombre propio se añade"; en el renombre puede encontrar acomodo, además de "titulos de dignidad y ofizios onrrosos" (Correas: deán, comendador, secretario, etc.), "algún accidente", esto es, algún atributo del nombrado que lo señala entre los demás; el renombre no aporta información sobre el linaje (a menos que se herede) sino, lo que es más importante, sobre alguna propiedad que pertenece al nombrado como ser puramente individual.

El conjunto de estos elementos nominadores (tratamiento, nombre, sobrenombre y, en parte, el renombre) identifica a los individuos en su faceta de seres sociales, ya sea por la filiación, ya sea por el rango, de modo que el nombre completo que utiliza la persona ofrece información acerca de su inserción en la sociedad. Pero también es cierto que, en tiempos de Cervantes, la permisividad generalizada para atribuirse el don o para cambiar de sobrenombre falsea esa información; recurriendo a esas modificaciones y tergiversaciones

10. Arte de la lengua..., p. 210. La elección de nuevo sobrenombre, siempre según CORREAS, recae sobre los patronímicos, sobre el recuerdo de algún hecho memorable, sobre lugares o sobre adjetivos recategorizados que aluden al origen o al oficio.

11. Sebastián de Covarrubias, Tesoro de la lengua castellana o española, edición de Felipe C. R. Maldonado, Madrid, Castalia, 1994, p. 438. 
resultaba posible adoptar un nombre moldeado sobre pretensiones más que sobre realidades ${ }^{12}$.

\section{El NOMBRE DEL HIDALGO}

El primer párrafo del capítulo inicial del Quijote describe un hidalgo manchego en sus rasgos más externos y superficiales. La descripción inicial se atiene a la imagen del hidalgo de aldea ya explanada por fray Antonio de Guevara en 1539. Cervantes parece seguir muy de cerca a fray Antonio en la enumeración de los atributos de ese hombre inmerso en una aurea mediocritas de raigambre horaciana; como propio de ese hombre alejado del tráfago cortesano, Guevara menciona la ociosidad y la afición a la caza, presentes en el hidalgo cervantino, y unos utensilios característicos ("una lanza tras la puerta, un rocín en el establo, una adarga en la cámara"13) que también Cervantes acomoda a su personaje ("un hidalgo de los de lanza en astillero, adarga antigua, rocín flaco y galgo corredor"). Añade Cervantes una rápida enumeración de sus hábitos gastronómicos e indumentarios, así como de las personas que se desenvuelven en casa del hidalgo (ama, sobrina y mozo).

La primera vez que nombra a este personaje, la voz del narrador deja su nombre en la penumbra de una imprecisión que no llegará a disiparse hasta el capítulo final:

Quieren decir que tenía el sobrenombre de Quijada, o Quesada, que en esto hay alguna diferencia en los autores que deste caso escriben; aunque, por conjeturas verosímiles, se deja entender que se llamaba Quejana ${ }^{14}$. Pero esto importa poco a nuestro cuento; basta que en la narración dél no se salga un punto de la verdad (I.1).

Es llamativo que el narrador no ofrezca ninguna certeza sobre el nombre, sino apenas un vago acercamiento; lo menciona entremezclando las voces de desconocidos autores, igualadas en la incertidumbre de un discurso indirecto modalizado por la perífrasis que lo introduce, "quieren decir", y por la mención de las "conjeturas verosímiles", aunque no hay evidencia de la verosimilitud a que alude. La vaguedad en que queda sumido el verdadero nombre del protagonista de la historia permanece cuando, unos párrafos más adelante, este se otorga a sí mismo nuevo nombre:

12. De ello dan buena muestra los maliciosos versos que QuEvedo escribe sobre "el doctor Juan Pérez de Montalbán": "El doctor tú te lo pones, / el Montalbán no lo tienes, / con que, quitándote el don / vienes a quedar Juan Pérez".

13. Antonio De Guevara, Menosprecio de corte y alabanza de aldea. Arte de Marear, edición de Asunción Rallo, Madrid, Cátedra, 1984, p. 181.

14. La edición príncipe menciona esta variante del apellido, como la mayor parte de los editores modernos. FRANCISCO RICO atribuye esta forma del sobrenombre del personaje a errata del impresor y corrige en "Quijana", como Pedro Alonso llama a don Quijote en el capítulo quinto (véase "Quexana", Euphrosyne, XXII, 1994, pp. 431-439). El que sea "Quijana” o "Quejana” no invalida nuestro análi- 
Al cabo se vino a llamar don Quijote, de donde -como queda dicho- tomaron ocasión los autores desta tan verdadera historia que, sin duda, se debía de llamar Quijada, y no Quesada, como otros quisieron decir (I.1).

Atenuando la fuerza de sus afirmaciones mediante expresiones modalizadoras ("sin duda", "se debía de llamar"), la voz del narrador vuelve aquí a fijar su atención en las discrepancias entre las distintas fuentes que supuestamente ha utilizado para construir una historia que no puede empezar con la reconstrucción del nombre del protagonista.

Ninguna de las características que se atribuyen al personaje en el párrafo inicial singularizan a la persona en que se concretan, incluido su nombre. Por el contrario, Cervantes toma en cuenta todo aquello que lo iguala con un tipo social de mediano estado venido a menos. Se trata de uno entre muchos ("un hidalgo de los de...") cuyos caracteres definitorios valen en 1605 lo mismo que valían en 1539: son rasgos que definen un tipo, no un individuo. El autor describe un ser perfectamente cambiable por cualquier otro si no se alteran los puntos de referencia que concurren en esta primigenia identificación; el personaje es un hidalgo insignificante. La vida que el hidalgo ha llevado entre bastidores, la anterior al arranque de la novela, cabe en un párrafo y está dominada por la continuidad, por el estatismo que los pretéritos imperfectos confieren al mundo representado en estas pocas líneas. El personaje no carece de pre-historia, como creía Unamuno, sino que esta abarca un lapso informe en el que, salvo cuestiones de detalle, todo permanece idéntico a sí mismo; la prehistoria, lejos de servir para individualizar al hidalgo, ha dado como resultado el ir sumiéndolo en una mediocre indiferenciación anuladora de cualquier destello personal.

La imprecisión con que se alude al nombre del personaje está en lógica correspondencia con su irrelevancia, pues las distintas variantes que se apuntan apenas son suficientes para distinguirlo entre sus iguales. La concurrencia de varias posibilidades nominativas en el capítulo inicial revela una percepción confusa de la realidad personal del hidalgo; no se trata tanto de la confluencia de varias perspectivas cuanto de la falta de una perspectiva auténticamente clarificadora. En el fondo, el nombre del hidalgo es indiferente en este punto de la narración, se trata de un don nadie carente de individualidad, que porta un nombre "sin estruendo", tan plano como su propia vida anterior a la historia que va a narrarse. Y cada vez que aparece un nuevo sobrenombre, se reaviva la dudosa veracidad de todas las posibilidades mencionadas anteriormente en el texto. En el capítulo quinto, por ejemplo, un vecino de don Quijote, Pedro Alonso, lo llama "señor Quijana". Aunque este sobrenombre aparece ya en la historia de don Quijote, remite a su incierta pre-historia. Pedro

sis, pues en este punto no se trata del nombre del personaje, sino de una posibilidad entre otras de que el personaje se llame de esa manera. En este trabajo se citará el Quijote por la edición de FLORENCIO Sevilla Arroyo y Antonio Rey Hazas (Madrid, Alianza Editorial, 1996), sin más indicación que la parte (en números romanos) y el capítulo (en numeración arábiga). 
Alonso sabe, o al menos cree saber, cómo se llama el personaje, pero no por ello la autenticidad del sobrenombre Quijana deja de ser puesta en entredicho, pues el narrador intercala en la intervención de Pedro un paréntesis modalizador similar a los del capítulo inicial:

-Señor Quijana -que así se debía de llamar cuando él tenía juicio y no había pasado de hidalgo sosegado a caballero andante-, ¿quién ha puesto a vuestra merced desta suerte? (I.5).

De este modo, parece que el narrador se desentiende del nombre del hidalgo, como si lo considerara asunto carente de interés que enlaza con otro aspecto llamativo de la indeterminación del nombre: el de la poca relevancia -"esto importa poco a nuestro cuento"- que el narrador afirma conceder a este detalle; lo esencial, según afirma, es la veracidad de la narración.

¿Qué sentido tiene el hecho de que, en el punto de partida de la narración, las varias formas del nombre del protagonista no se perciban como obstáculo para la verdad de la historia? Quijana, Quijada, Quesada revelan la convención cultural a que está sometida la imposición de nombre: singularizar a la persona. El nombre se recibe, por convención social, heredado de los antepa$\operatorname{sados}^{15}$ y funciona como señal que permite reconocer a un hombre como un ser distinto de otros hombres, sin aportar otra información sobre la personalidad del nombrado que no sea la de no confundirlo con otra persona y la de relacionarlo, generalmente, con sus ascendientes, según hemos visto en el Arte de Correas. Un nombre u otro son importantes para el conocimiento de la persona, pero no son suficientes para determinar la mismidad del nombrado. En este sentido afirma Cervantes la falta de importancia del nombre para la verdad del caso: a la verdad atañe de pleno la tarea de revelar el ser de las cosas o de los hombres, mientras que queda en plano muy secundario la de hacer patente el conocimiento que los hombres tienen de las cosas o de los otros hombres. En cualquier caso, el autor distingue palpablemente entre las cosas y el conocimiento que de ellas se tiene ${ }^{16}$.

Que el nombre del hidalgo carezca de importancia para la verdad del caso se explica si se parte del presupuesto de que lo sustancial del caso no está en el hidalgo mismo, sino en su conversión en don Quijote. La insignificancia que ha dominado la vida del hidalgo es perfectamente relevante para el caso que la novela va a desarrollar, que no es otro que el paso de "don nadie" a don Quijote y el de don Quijote a Alonso Quijano. En ninguno de estos tres estadios sucesivos el personaje es exactamente de la misma manera que en los

15. En la conversación con el canónigo de Toledo (I.49), don Quijote dice ser descendiente de Gutierre Quijada, de quien hereda el sobrenombre.

16. Los personajes de El retablo de las maravillas, por ejemplo, no aceptan esta distinción, sino que sitúan la percepción de la realidad en plano más relevante que la realidad misma. De este modo, se llega ahí a situar la verdad en la convención, en un implícito consenso entre los rústicos ajeno al ser de las cosas. Tarde o temprano, la insobornable realidad del mundo, traída de la mano del Furrier en este entremés, pasa factura a quienes le vuelven la espalda. 
otros dos, pero al mismo tiempo no deja de ser él mismo, de modo que la narración viene a mostrarse como el despliegue de una identidad individual en varias etapas intensamente trabadas entre sí. En un primer momento, que comprende el primer capítulo, el personaje se resiste a asumir la concreción de su identidad en el molde de unas formas dominadas por convenciones que siente insuficientes para la realización plena de su persona; en esa insatisfacción del hidalgo se engendra don Quijote. En una segunda etapa, ya como don Quijote, el personaje se acepta como un proyecto de sí mismo que está por realizarse, y pugna por llevarlo a cabo; el choque entre la conciencia de sí mismo y las imposiciones del medio social convierten en inviable la empresa del caballero. Y de la imposibilidad de integración del yo de don Quijote en el mundo nace la última etapa, reducida al capítulo final, en la que Alonso Quijano se acepta como el hidalgo del capítulo inicial y como el caballero de los restantes. De lo dicho se desprende que entre el hidalgo, don Quijote y Alonso Quijano hay una continuidad no exenta de muchos y ricos matices; en el hidalgo está el germen de don Quijote y en don Quijote, el fundamento de Alonso Quijano.

El telón de fondo de la insistencia en la veracidad de la historia y en las discrepancias entre los supuestos "autores" que de ella se han ocupado es la parodia de la novela caballeresca. La novela de caballerías trata de presentarse, desde dentro del relato, como narración histórica que da cuenta de la vida de un héroe extraordinario inserto en un mundo no menos extraordinario, pero periclitado en el momento de la difusión de la historia: el mundo caballeresco ya se ha extinguido y no es posible reconstruirlo desde el presente. El único nexo entre ese mundo y el mundo del lector es el propio relato, pero dada la desmesurada distancia entre el mundo del que habla el relato y el mundo en el que se difunde, el narrador siente la necesidad de acreditar el contar mencionando fuentes extraordinarias que lo justifiquen. A este recurso acude Rodríguez de Montalvo en el prólogo de Amadís de Gaula, donde dice traducir de un raro manuscrito "que por gran dicha paresció en una tumba de piedra, que debaxo de la tierra en una hermita, cerca de Constantinopla fue hallada, y traído por un úngaro mercadero a estas partes de España, en letra y pargamino tan antiguo, que con mucho trabajo se pudo leer por aquellos que la lengua sabían"17. Parecida justificación fabulosa se da de otros textos caballerescos del siglo $\mathrm{XVI}^{18}$. En relación con estas prácticas halla su sentido la invención de

17. Garci Rodríguez de Montalvo, Amadís de Gaula, I, edición de Juan Manuel Cacho Blecua, Madrid, Cátedra, 1991, pp. 224-225.

18. El Baladro del sabio Merlín se hace pasar por traducción de un original escrito por el propio Merlín, DiEgo ORTúÑEZ DE CALAHORRA dice elaborar su Espejo de príncipes y caballeros a base de traducir los relatos de los sabios Artemidoro y Lirgandeo, personajes de la propia obra, y, como señala E. C. RILEY (Introducción al Quijote, Barcelona, Crítica, 2000, p. 53), Don Cirongilio de Tracia y Felixmarte de Hircania se justifican como traducciones de inexistentes textos antiguos a los que habrían aportado su colaboración fabulosos autores o el mismísimo Petrarca. Recurrir a estos hallazgos extraordinarios es, por lo demás, frecuente en la novela histórica española de los últimos años, aun cuando su función no sea exactamente la misma que la de los libros caballerescos; así, novelas como, por ejemplo, Yo, el Rey, de J. A. VALlejo-NÁGERA, o El manuscrito carmesí, de A. GALA, hallan su jus- 
Cide Hamete Benengeli en el Quijote; pero antes incluso de que se llegue a ese momento, el narrador ha puesto en marcha ese mismo procedimiento mencionando, con ocasión de la inconcreción del nombre del protagonista, las discrepancias entre "los autores que deste caso escriben". Al lector de novelas caballerescas las ficciones se le ofrecen como biografías históricas, donde lo excesivo de los hechos parece corresponder a los excesos del mundo más que a la imaginación de unos autores que justifican su hacer en la transliteración de un escrito autorizado por la garantía de sus fuentes. Como después se hará más patente con Cide Hamete y con la mención de los inexistentes Anales de la Mancha, no carecen de sorna las referencias del primer capítulo del Quijote a los imaginarios historiadores que supuestamente habrían abordado ya la biografía de don Quijote. Esos imaginados biógrafos, que nunca salen del anonimato, discrepan en dato tan empíricamente verificable como un nombre y el contenido de sus aportaciones es reproducido en un discurso indirecto marcadamente modalizado ya sea mediante locuciones ("sin duda") o mediante perífrasis ("quieren decir", "se debía de llamar", "se deja entender") que marcan una correspondencia dudosa entre el contenido de lo dicho y la realidad a que se alude con la palabra. Las protestas de veracidad, la modalización de las fuentes y las discrepancias entre ellas desempeñan la función de separar la paja del grano, o, lo que es lo mismo, distinguir entre la veracidad del caso y la relatividad del conocimiento que de ese caso tienen los ficticios historiadores mencionados por Cervantes.

Como, según más delante dice el canónigo de Toledo, "hanse de casar las fábulas mentirosas con el entendimiento de los que las leyeren" (I.47), resulta procedente dejar clara desde el principio la distancia entre las cosas y las palabras con objeto de no confundir las unas con las otras. No las distingue, sin embargo, el hidalgo lector, a quien "asentósele de tal modo en la imaginación que era verdad toda aquella máquina de aquellas sonadas soñadas invenciones que leía, que para él no había otra historia más cierta en el mundo" (I.1), y de esa confusión le viene la pérdida del juicio, que lo lleva a transformarse en don Quijote de la Mancha.

\section{Don Quijote de la Mancha}

Tomada la decisión de hacerse caballero andante, el hidalgo siente la necesidad de singularizarse por el número y calidad de las hazañas que pretende a llevar a cabo. En correspondencia con ese afán de singularización, surge la necesidad de encontrar nuevo nombre para sí mismo, para su caballo y para la señora de sus pensamientos, habida cuenta de que al nombre fía una doble función: la de distinguir al nombrado de otros seres que forman parte de la misma serie y la de reflejar sus calidades. Después de emplear cuatro días en dar

tificación narrativa en el hecho de presentarse como las memorias de José Bonaparte y de Boabdil, respectivamente. 
nombre a Rocinante, el protagonista gasta otros ocho días en dárselo a sí mismo, al cabo de los cuales "se vino a llamar don Quijote"; y, no contento con ello, completa la nominación con el nombre de su patria:

Acordándose que el valeroso Amadís no solo se había contentado con llamarse Amadís a secas, sino que añadió el nombre de su reino y patria, por Hepila ${ }^{19}$ famosa, y se llamó Amadís de Gaula, así quiso, como buen caballero, añadir al suyo el nombre de la suya y llamarse don Quijote de la Mancha, con que, a su parecer, declaraba muy al vivo su linaje y patria, y la honraba con tomar el sobrenombre della (I.1).

Los tres elementos del nombre del caballero ("Don", "Quijote" y "de la Mancha") hallan motivación en la imaginación del personaje. En contraste con el nombre del hidalgo, adquirido de la convención cultural, el nuevo nombre que se da a sí mismo es una creación que el personaje ha elaborado aplicando un doble criterio: 1) que sea "significativo", es decir, que revele el ser de su portador ${ }^{20}$; y 2) que sea "famoso y de estruendo", como corresponde a la onomástica caballeresca ${ }^{21}$.

A juicio del personaje, el de Rocinante es nombre "alto, sonoro y significativo", como "músico y peregrino y significativo" es no solo el de Dulcinea, sino también "todos los demás que a él y a sus cosas había puesto". La necesidad de nuevo nombre radica en el cambio que el personaje ha experimentado, como explica en el momento de imponérselo a Rocinante -el primero en ser nombrado conforme a los criterios antedichos-, "pues estaba muy puesto en razón que, mudando su señor estado, mudase él también el nombre", y "no era razón que caballo de caballero tan famoso, y tan bueno él por sí, estuviese sin nombre conocido".

El primero de esos cambios se refleja en el honorífico don, que se une a Quijote en un todo invariable ${ }^{22}$, como un sintagma fijo, no solo en la obra de Cervantes sino en las menciones que de este personaje se hacen en el siglo XVII. El personaje hace empezar su nombre por el don honorífico, tratamiento que se atribuye sin justificación explícita; el hidalgo no puede legítimamente anteponer don a su nombre sin caer en la soberbia. Pero la anteposición se justifica de manera implícita: el personaje ya no se ve a sí mismo como simple hidalgo, sino como caballero, y como a los caballeros le es legítimo añadirse ese tratamiento, que considera elemento "significativo" de la nueva calidad de su persona. Por otra parte, aunque no obligada, la mención del trata-

19. Así en el texto de la edición por la que citamos, que lo toma de la editio princeps (p. $3 \mathrm{v}$ ), mientras que la mayor parte de los editores considera Hepila errata y, de acuerdo con el sentido de la frase, corrigen por hacerla.

20. El personaje buscaba para el caballo un nombre "que declarase quién había sido, antes que fuese de caballero andante, y lo que era entonces" (I.1).

21. El nombre había de ser "famoso y de estruendo, como convenía a la nueva orden y al nuevo ejercicio que ya profesaba" (I.1).

22. Una sola vez se refiere el autor a su personaje sin anteponer don, llamándolo "nuestro gallardo Quijote" (I.9) 
miento era corriente en el modelo onomástico de la caballería, y de esa manera en la novela se alude frecuentemente a personajes como don Belianís, don Galaor, don Cirongilio, don Gaiferos, don Olivante, etc., serie a la que don Quijote se suma desde este momento.

El segundo cambio tiene su reflejo en el nombre Quijote. La voluntad de hallar nuevo nombre cristaliza en una fórmula tan respetuosa con la continuidad de la propia identidad como con la novedad del estado de caballero andante. El paralelo entre el nombre de don Quijote y el sobrenombre del hidalgo es tan evidente que el narrador se sirve de aquel para avalar una de las hipótesis sobre el verdadero apellido del hidalgo. En efecto, en el nombre de don Quijote la parte correspondiente a Quij- mantiene la identidad fónica de Quijada, Quijana, Quijano, lo que revela, como en el caso del caballo, "quién había sido". La novedad viene dada por el elemento -ote, revelador de la nueva condición, de "lo que era entonces", el cual lo pone en relación -como tantas veces se ha repetido- con nombres caballerescos de idéntica terminación, como Lanzarote del Lago, Morlote de Irlanda, Angriote de Estraváus o Camilote, aunque es poco probable que este último llegara a pesar en la conciencia del caballero manchego ${ }^{23}$. Formalmente idéntica a un sufijo despectivo y aumentativo a la vez, la terminación -ote carece de este valor en Lanzarote, Morlote, Angriote o en Quijote; el sufijo determina el significado de su base (Camilo en Camilote, como caballero en caballerote) pero ni el significado de Quij- ni el de Lanzar-, Morl- o Angri- son reconocibles como bases semánticamente determinadas por la terminación de estos nombres. Ni siquiera lo es en otro nombre cervantino, Ricote, que, aun cuando pueda relacionarse con el adjetivo rico, como nombre propio está lexicalizado y se percibe como palabra inanalizable en los significados de sus constituyentes (rico y -ote). De atribuir a -ote el valor del sufijo, don Quijote se habría hecho llamar Quijanote o Quijadote. No ha sido así, y eso revela que la confluencia entre su propio nombre y los de Lanzarote, Morlote o Angriote se reduce a la semejanza fónica de la parte final.

Finalmente, el añadido de la Mancha no solo revela la procedencia local del personaje (tanto del hidalgo como del caballero), sino que también entra en correlación con Gaula, Grecia, Niquea o Hircania en la nominación del "buen caballero", que toma a su cargo honrar a la patria incorporándola como sobrenombre. Escogiendo el topónimo como sobrenombre sigue don Quijote un proceder no infrecuente en la época, según testimonia Correas: "Otros [so-

23. DÁmaso Alonso ("El hidalgo Camilote y el hidalgo don Quijote", Revista de Filología Española, XX, 1933, pp. 391-397), cree que el personaje de Cervantes guarda relación con un personaje de Gil Vicente, el cual lo habría tomado de Primaleón y Polendos, que lleva el nombre de Camilote. A pesar de los paralelismos que D. Alonso aprecia entre Camilote y don Quijote (pp. 392-393) no nos parece plausible que en la génesis del personaje cervantino pesaran ni el vicentino ni el del relato caballeresco, pues Cervantes dota a don Quijote de una dimensión trágica de la que carecen esos otros personajes. Tampoco parecen guardar otra relación formal que la terminación en -ote; sin embargo, en el caso de Camilote este elemento corresponde al significado del sufijo que en castellano tiene esta misma forma. 
brenombres] se tomaron de lugar i de otras cosas, i unos llevan de de genitivo o ablativo, que denota el lugar, parte o cosa de donde se tomaron" 24 .

Así, pues, el nombre del caballero, como el de su caballo y como el de su dama, sí que es "significativo" y ese significado se justifica desde el texto mismo como una consciente y trabajosa decisión adoptada por el personaje. Pero no debe confundirse el modo de significar del nombre propio con el nombre común. El significado del nombre propio no se ha de entender como una descripción del nombrado, mientras que el del nombre común, en términos muy generales, sí que constituye una descripción de lo nombrado; la expresión "don Quijote" no describe al personaje, mientras que "caballero" sí que describe a un caballero. La distinción estriba en que el nombre común tiene un valor representativo del que carece el nombre propio. Uno y otro tienen un valor convencional, pero mientras que la convención del nombre común tiene extensión universal en la comunidad de los hablantes de una lengua (si no tenemos en cuenta los significados asociativos ligados a las palabras), la del nombre propio es mucho más reducida; cualquier hablante de castellano, por el hecho de hablar esa lengua, se refiere a la persona $\mathrm{X}$ con la palabra "hombre" o al animal Y con "caballo", pero no tiene por qué saber si el hombre se llama Alonso Quijano o don Quijote o si el caballo se llama Rocinante. El significado de "don Quijote" no se ha de ver tanto en el valor representativo del nombre cuanto en su semejanza con el nombre del hidalgo y con los nombres caballerescos y, sobre todo, en lo que representa la acción de autoimponerse tal nombre; la imposición de nuevo nombre revela la visión que de sí tiene el personaje y la intención del hidalgo que lleva a cabo el acto de nombrarse; "las obras que se hacen declaran la voluntad que tiene el que las hace" (II.62), dice Cervantes, y en la creación de su nuevo nombre el hidalgo evidencia la de singularizarse remitiendo a quien es (el hidalgo) y a quien tiene voluntad de ser (el caballero andante).

En el paso del ser al querer ser, materializado en el cambio de nombre, no se produce un cambio radical, como a veces se afirma, en la identidad del personaje. Es el hidalgo el que crea al caballero y el hidalgo quien le da nombre; Torrente Ballester ${ }^{25}$ y Castilla del Pino ${ }^{26}$ sostienen que don Quijote es un personaje ideado por el hidalgo y Riley subraya el paralelo entre las dos vertientes del personaje y los juegos infantiles, en los que se asume un papel sin perder la conciencia de $\mathbf{s i}^{27}$. Pero el hidalgo no juega a ser otro. Entre el hidalgo

24. Gonzalo Correas, Arte de la lengua española castellana, p. 210.

25. "El autor de la novela, por medio del narrador, inventa un personaje, Alonso Quijano, quien, a su vez, inventa a don Quijote, y disfrazado de este sale al campo en busca de aventuras. La relación entre él, Alonso Quijano, y el personaje, don Quijote, es semejante, en parte, a la que existe en el teatro entre actor y personaje", dice GonZALO TORRENTE BALLESTER (El Quijote como juego y otros trabajos críticos, Barcelona, Destino, 2004, p. 58; la primera edición de El Quijote como juego data de 1975).

26. Carlos Castilla del Pino, Cordura y locura en Cervantes, Barcelona, Península, 2005, pp. 44-48.

27. EdWARD C. Riley, "Quién es quién en el Quijote", pp. 39-40. 
y don Quijote hay una continuidad psicológica evidente: las experiencias de uno y otro remiten a una misma conciencia a lo largo de todo el tiempo ${ }^{28}$; su casa y sus pertenencias son las mismas ${ }^{29}$; su sobrina, su ama y sus conocidos, también, así como uno mismo es su espacio y su tiempo. Sobre ese sustrato básico, psíquico y cultural a un tiempo, se asienta la identidad única de hidalgo y caballero.

No obstante, sí se produce un importante cambio en los valores a los que el personaje se adhiere. El hidalgo siente insuficiente, falta de plenitud, su identidad inicial y, no conforme con lo que es, se aventura a querer ser otra cosa sin dejar de ser él mismo. Tal como lo describe Cervantes en el primer capítulo, la identidad del oscuro hidalgo manchego se funda sobre su pertenencia a un grupo; como parte de un todo, lo sustancial de la identidad no radica en el individuo, sino en el grupo al que pertenece, y se concreta en unos atributos sociales y culturales. En gran medida, el individuo no puede vivir para sí sin el asentimiento del grupo: el hidalgo es lo que es en la medida en que es reconocido. Dentro de esas coordenadas, la identidad está cumplida, cerrada y solo puede modificarse si varía la posición del individuo dentro del grupo. Pero cuando el hidalgo crea a don Quijote, las cosas se revelan muy distintas. Ya no siente que el núcleo de la identidad individual esté en pertenecer a tal o cual grupo, sino en la aspiración a un ideal de justicia universal; ahora se siente ser él mismo en la medida en que asiente a la realización del ideal y participa en ella, lo cual exige no una posición social, sino una decisión personal, un acto íntimo de la voluntad. Respecto del grupo, el individuo ya no es una parte de él, sino un todo plenamente autónomo que no requiere, para ser él mismo, el permiso de los demás. El punto central de esta otra concepción de la identidad está en tender a una meta infinita, nunca completamente lograda, porque el ideal carece de realización histórica. Ahora bien, el hombre sí está sometido al imperio del tiempo y la vida, necesariamente temporal, consagrada a la realización de un ideal que está fuera del tiempo es una tarea nunca acabada. En este sentido, la identidad no deja de ser un proyecto en permanentemente realización y actualización, siempre cumplido con respecto al pasado y siempre abierto a cumplirse en el futuro.

Esa mutación de valores no anula, sin embargo, la continuidad del personaje como conciencia de una sola mismidad. Cuando Pedro Alonso lo en-

28. Don Quijote tiene recuerdos que, en puridad, no deberían pertenecerle a él, sino al hidalgo; su amor a Dulcinea-Aldonza es anterior a la creación del caballero andante: "En doce años que ha que la quiero más que a la lumbre destos ojos que han de comer la tierra, no la he visto cuatro veces; y aun podrá ser que destas cuatro veces no hubiese ella echado de ver la una que la miraba: tal es el recato y encerramiento con que sus padres, Lorenzo Corchuelo, y su madre, Aldonza Nogales, la han criado", revela a Sancho Panza (I.25).

29. Don Quijote dispone libremente de bienes que deberían corresponder al hidalgo, y sin más le ofrece a Sancho: "En albricias destas no esperadas como buenas nuevas, te mando el mejor despojo que ganare en la primera aventura que tuviere, y si esto no te contenta, te mando las crías que este año me dieren las tres yeguas mías, que tú sabes que quedan para parir en el prado concejil de nuestro pueblo" (II.10). 
cuentra tendido en el campo manchego, en el personaje confluyen las dos caras de su identidad:

-Mire vuestra merced, señor, pecador de mí, que yo no soy don Rodrigo de Narváez, ni el marqués de Mantua, sino Pedro Alonso, su vecino; ni vuestra merced es Valdovinos, ni Abindarráez, sino el honrado hidalgo del señor Quijana.

-Yo sé quién soy -respondió don Quijote-; y sé que puedo ser no solo los que he dicho, sino todos los Doce Pares de Francia, y aun todos los Nueve de la Fama, pues a todas las hazañas que ellos todos juntos y cada uno por sí hicieron, se aventajarán las mías (I.5).

La respuesta de don Quijote trasluce que hidalgo y caballero están fundidos en uno. Oyéndose llamar Quijana, el personaje se reconoce en quien es ("Sé quién soy"), pero también se activa en él la posibilidad de ser otra cosa ("Sé que puedo ser"); el nexo entre lo actual y lo potencial es la conciencia de una identidad fluyente. Concebida como desarrollo cursivo, la identidad se proyecta siempre hacia el futuro y puede integrar y redimir el pasado en el presente; en don Quijote se acepta el hidalgo a sí mismo y se salva de una vida gris. Comentando este pasaje, Unamuno destacaba la voluntad de ser del personaje ${ }^{30}$, Ramón Rodríguez señala una decidida "tensión vigilante hacia el futuro" como motor de la conciencia de la identidad del personaje ${ }^{31}$, y Riley, una afirmación de la identidad que raya en el heroísmo al tiempo que un matiz fantasioso y megalómano ${ }^{32}$. Las palabras de don Quijote en respuesta a Pedro Alonso se han interpretado como síntoma de enajenación; pero cuando dice "Yo sé quién soy" no parece que el personaje crea ser alguien distinto de él mismo, pues el antecedente del atributo quién puede referirse no solo a los nombres mencionados (Valdovinos y Abindarráez) sino a ellos y al propio yo conjuntamente, según señala Torrente Ballester ${ }^{33}$. Esta interpretación es más plausible, pues anticipa el atributo (no solo los que he dicho, sino...) del inmediatamente subsiguiente puedo ser, donde se explana más extensamente la identificación de don Quijote. Por otra parte, se ha de tener en cuenta que don Quijote hace explícita mención del motivo que lo lleva a igualarse con esos personajes de ficción ("las hazañas que ellos todos juntos y cada uno por sí hicieron"), por lo que no cabe interpretar que cuando menciona a Valdovinos y Abindarráez crea ser cualquiera de ellos sino en esa misma medida de verse retratado en los hechos -pero no en el "yo"- de estos personajes.

En cualquier caso, no hay quiebra, sino clara continuidad entre hidalgo y caballero en el sustrato más básico de su identidad, lo cual no excluye que se den muy claras diferencias, de modo paralelo a lo que sucede en el desenvol-

30. Miguel de Unamuno, Vida de Don Quijote y Sancho, edición de Alberto Navarro, Madrid, Cátedra, 1992, p. 191.

31. RAMÓN RodríGuez, Del sujeto y la verdad, Madrid, Síntesis, 2004, p. 106.

32. RILEY, "Quién es quién en el Quijote", p. 40.

33. El Quijote como juego..., p. 62. 
vimiento de los nombres del personaje. En los primeros párrafos, el hidalgo no está individualizado y es casi innombrable por la falta de seguridad sobre cuál de los distintos sobrenombres sería el que verdaderamente le correspondiera; don Quijote está individualizado plenamente y su nombre aparece de manera inequívoca, no cabe ya la duda. En don Quijote es reconocible la forma del apellido del hidalgo como es reconocible la voluntad de cobrar "eterno nombre y fama" materializándolo en una forma distinta, a la cual habrían de dar contenido las hazañas del caballero.

\section{Sentido asociativo Del NOMBRE}

Al imponerse nuevo nombre, el personaje evidencia una voluntad de representarse plenamente válida para él. Dándose nombre, instaura una convención nueva (una nueva relación entre nombre y persona) que sustituye a la que le había otorgado, previamente, el nombre de Quijada, Quesada o Quijana. En el hablar se transmiten, de manera explícita, palabras y, de manera implícita, la convención que las legitima. Cuando el personaje dice ser don Quijote de la Mancha o el narrador lo identifica con este nombre, se hace partícipe a otro de una expresión que tiene el contenido que tiene y el destinatario la relaciona con su previa experiencia de las cosas y de la práctica comunicativa. En relación con su experiencia de las cosas, el destinatario aprecia si lo comunicado tiene correspondencia con su percepción de lo real y valora hasta qué punto se ajustan la expresión recibida y la propia percepción de las cosas. En relación con la práctica comunicativa, el destinatario asocia la expresión con otras expresiones preexistentes, de las cuales posee previa experiencia, y construye el contenido de lo comunicado amalgamando, por una parte, el significado transmitido por el hablante y, por otra, los sentidos asociativos que la expresión le suscita en el momento de la comunicación. Y de ahí surge el conflicto de la falta de correspondencia entre el sentido de lo que se transmite y el de lo que se recibe.

Ese conflicto se muestra repetidas veces en el Quijote; los personajes del mundo representado en la novela cuestionan la propiedad o la veracidad de lo que se dice, negando legitimidad, por ejemplo, al hecho de que don Quijote pueda llamarse don Quijote, o asociando de la Mancha con mundos de referencia muy distintos de los que don Quijote considera presentes en esta expresión. Esa falta de propiedad se detecta, también, en la comunicación entre autor y lector, en la que pueden actualizarse unos valores connotativos que prestan al nombre un sentido muy diferente del que le otorga el personaje. La cuestión que hay que resolver en este nivel de la comunicación es la de dilucidar si Cervantes dio a don Quijote el nombre que le dio obedeciendo a una voluntad de suscitar esas asociaciones y, en caso de que así fuera, establecer cuáles son esos sentidos connotativos y qué alcance tienen en la obra.

Varios niveles de significación se congregan en cada uno de los elementos que componen el nombre del caballero manchego; expuesto ha quedado en el apartado anterior el significado que don Quijote atribuye a su nombre, en este 
examinaremos qué sentido perciben los otros personajes de la ficción y, por encima de ellos, el que el autor mismo otorga a los componentes del nombre don Quijote de la Mancha.

\subsection{El tratamiento honorífico}

El empleo del don honorífico es un punto conflictivo en el mundo novelesco de Cervantes. Una cosa es la justificación que tiene para don Quijote y otra, muy distinta, la falta de ella que perciben otros personajes. La legitimidad que el uso de don tiene para don Quijote la ponen en entredicho en varias ocasiones personajes que pertenecen al mundo cotidiano en que se desenvuelve el hidalgo. La primera, cuando su vecino Pedro Alonso se dirige a don Quijote llamándolo dos veces "señor Quijana" (I.5), con un tratamiento de cortesía que carece de las connotaciones honoríficas de don. La segunda, al comienzo de la segunda parte, cuando a requerimiento de don Quijote ("¿Qué es lo que dicen de mí por ese lugar? ¿En qué opinión me tiene el vulgo, en qué los hidalgos y en qué los caballeros?") Sancho informa al caballero, antes que de otra cosa, de la rechifla que en el lugar ha causado el pomposo uso del don:

-Pues lo primero que digo -dijo-, es que el vulgo tiene a vuestra merced por grandísimo loco, y a mí por no menos mentecato. Los hidalgos dicen que, no conteniéndose vuestra merced en los límites de la hidalguía, se ha puesto don y se ha arremetido a caballero con cuatro cepas y dos yugadas de tierra y con un trapo atrás y otro adelante. Dicen los caballeros que no querrían que los hidalgos se opusiesen a ellos, especialmente aquellos hidalgos escuderiles que dan humo a los zapatos y toman los puntos de las medias negras con seda verde (II.2).

En la tercera, Teresa Panza se mofa ante Sancho de las pretensiones del hidalgo: "Yo no sé, por cierto, quién le puso a él don, que no tuvieron sus padres ni sus agüelos" (II.5). Y en una cuarta ocasión, la sobrina trata en vano de desengañar a don Quijote de su condición de caballero:

-¡Válame Dios! -dijo la sobrina-. ¡Que sepa vuestra merced tanto, señor tío, que, si fuese menester en una necesidad, podría subir en un púlpito e irse a predicar por esas calles, y que, con todo esto, dé en una ceguera tan grande y en una sandez tan conocida, que se dé a entender que es valiente, siendo viejo, que tiene fuerzas, estando enfermo, y que endereza tuertos, estando por la edad agobiado, y, sobre todo, que es caballero, no lo siendo; porque, aunque lo puedan ser los hidalgos, no lo son los pobres! (II.6).

Es obvio que el protagonista no se percibe a sí mismo como los otros lo perciben. El genérico y educado señor Quijana de Pedro Alonso, las críticas de los hidalgos y caballeros del lugar manchego, la mofa de Teresa y la reprensión de la sobrina se dirigen a un hombre cuyo puesto en el armazón so- 
cial está bien determinado y no corresponde a las ínfulas de hacerse llamar don; podemos decir que la de estos personajes es la percepción social del hidalgo. Sin embargo, don Quijote tiene de sí una percepción que concede más vigor a lo moral que a lo social, donde la voluntad de ser tiene primacía sobre el ser socialmente determinado, y al darse el tratamiento honorífico no se atiene estrictamente al lugar que ocupa en la escala social, sino más bien al valor moral de su persona. El punto de encuentro entre estas dos visiones del personaje es la polivalencia de la palabra "caballero", que no solo se emplea para designar un estamento sino también un comportamiento gobernado por muy estrictas reglas éticas. En el primero de estos sentidos lo emplean quienes rodean a don Quijote; este, en cambio lo emplea en el sentido moral ${ }^{34}$; en el sentido social, la condición del caballero queda fijada en el linaje y la riqueza, pero en el sentido moral son las actitudes del individuo las que forjan al caballero. Don Quijote tiene conciencia de que entre lo moral y lo social hay un nexo que hace legítima la utilización del tratamiento ${ }^{35}$, ya que se ve a sí mismo como el ser que es en potencia; sin embargo, los otros personajes no aprecian que tenga correspondencia con el ser actual del hidalgo, lo cual conduce a negar legitimidad al hacerse llamar don Quijote.

En mostrar dentro del mundo novelesco el controvertido uso del honorífico por el uno y la desautorización por los otros puede palparse que el autor carga contra la costumbre, frecuente en la época, de adjudicárselo convenga o no a la calidad de la persona que se lo atribuye ${ }^{36}$. La desenvoltura con que lo aceptan la Tolosa y la Molinera (I.3) es bien ilustrativa. Por otra parte, el uso

34. "Ni todos los que se llaman caballeros lo son de todo en todo: que unos son de oro, otros de alquimia, y todos parecen caballeros, pero no todos pueden estar al toque de la piedra de la verdad. Hombres bajos hay que revientan por parecer caballeros, y caballeros altos hay que parece que aposta mueren por parecer hombres bajos; aquellos se levantan o con la ambición o con la virtud, estos se abajan o con la flojedad o con el vicio; y es menester aprovecharnos del conocimiento discreto para distinguir estas dos maneras de caballeros, tan parecidos en los nombres y tan distantes en las acciones" (II.6).

35. En el sentido social de la palabra, los atributos sociales son los rasgos distintivos del significado, mientras que el comportamiento moral es irrelevante; en el sentido moral, lo distintivo es el comportamiento y los atributos sociales, accidentales. En este sentido, dice don Quijote al ama y a la sobrina: "De todo lo dicho quiero que infiráis, bobas mías, que es grande la confusión que hay entre los linajes, y que solos aquellos parecen grandes y ilustres que lo muestran en la virtud, y en la riqueza y liberalidad de sus dueños. Dije virtudes, riquezas y liberalidades, porque el grande que fuere vicioso será vicioso grande, y el rico no liberal será un avaro mendigo; que al poseedor de las riquezas no le hace dichoso el tenerlas, sino el gastarlas, y no el gastarlas comoquiera, sino el saberlas bien gastar. Al caballero pobre no le queda otro camino para mostrar que es caballero sino el de la virtud, siendo afable, bien criado, cortés y comedido, y oficioso; no soberbio, no arrogante, no murmurador, y, sobre todo, caritativo" (II.6).

36. Las alusiones satíricas y las pullas hirientes motivadas por el uso de don son usuales en la literatura del tiempo de Cervantes. Del extenso florilegio que podría acumularse sobre el tema, valga como muestra representativa un ejemplo extraído de la Premática de los aranceles, de FRANCISCO DE QuEVEDO: "Habiendo advertido la multitud de dones que hay en nuestros reinos y repúblicas, y considerando el cáncer pernicioso que es y cómo se va extendiendo, pues hasta el aire ha venido a tenerle y llamarse don-aire, y mirando que imitan el pecado original en no escaparse de él nadie sino es Jesucristo y su Madre, mandamos recoger los dones, dando término de tres días, después de la notificación a todos los oficiales, para que se arrepientan de haberle tenido." 
de don intensifica el ultraje de don Quijote a Pasamonte cuando lo llama "don hijo de la puta" y "don Ginesillo de Paropillo" (I.22), de la misma manera que intensifica el que recibe don Quijote cuando se oye llamar "don Tonto" de labios de un eclesiástico (II.31). Esa fórmula ridiculiza, dentro y fuera de la novela, rimbombantes aspiraciones que tienen su contrapartida en el firme rechazo de Sancho Panza:

-Y ¿a quién llaman don Sancho Panza? -preguntó Sancho.

-A vuestra señoría -respondió el mayordomo-, que en esta ínsula no ha entrado otro Panza sino el que está sentado en esa silla.

-Pues advertid, hermano -dijo Sancho-, que yo no tengo don, ni en todo mi linaje le ha habido: Sancho Panza me llaman a secas, y Sancho se llamó mi padre, y Sancho mi agüelo, y todos fueron Panzas, sin añadiduras de dones ni donas; y yo imagino que en esta ínsula debe de haber más dones que piedras; pero basta: Dios me entiende, y podrá ser que, si el gobierno me dura cuatro días, yo escardaré estos dones, que, por la muchedumbre, deben de enfadar como los mosquitos (II.45).

Y lo mismo se evidencia en el no menos firme rechazo de Teresa ("Teresa me pusieron en el bautismo, nombre mondo y escueto, sin añadiduras ni cortapisas, ni arrequives de dones ni donas", II.5).

\subsection{El nombre Quijote}

Mayor atención ha recibido el significado asociativo que se atribuye al nombre mismo del personaje, en el cual se han apreciado matices relacionados con la simbología social y moral, con la visión carnavalesca, con alusiones sexuales y con la posible pertenencia del autor al grupo de los cristianos de origen judeoconverso.

Algún problema plantea la confluencia formal entre el nombre del caballero y el nombre común quijote, que en tiempo de Cervantes todavía circula (Covarrubias lo recoge en el Tesoro $^{37}$ ) para designar la parte de la armadura protectora de los muslos. Hay autores que sostienen que en el nombre del caballero resuena, con sentido simbólico, el significado del sustantivo común. En esta línea de interpretación están los trabajos de Constantino Láscaris ${ }^{38}$, E.

37. "En el arnés las piezas que cubren los muslos, cuasi cuxotes, de cuxa en italiano, que vale el muslo y del latino coxo", figura en la entrada Quijotes (p. 845), y en Gigote: "Es nombre francés, GIGOT, que vale pierna, conviene a saber la que es muslo en el hombre, y así pienso que la palabra quijotes, que son el armadura que cae sobre el muslo, está corrompida de gigotes, armadura de los muslos, como la de la rodilla abajo se llaman grevas" (p. 589).

38. A juicio de CONSTANTINO LÁsCARIs, Cervantes elige el nombre de don Quijote otorgándole un sentido metafórico no precisado, conforme al uso que ya le había dado Álvarez Gato en una composición amorosa en verso dedicada a su amiga (CONSTANTINO LÁSCARIS COMMENO, "El nombre de don Quijote", Anales Cervantinos, II, 1952, pp. 361-364). Los versos a que se refiere Láscaris son los siguientes: "Los quixotes serán tales / del afán que nunca afloxa; / las correas de los cuales / son dolores desiguales / con hevillas de congoxa" (p. 364). 
L. G. den Dooren de Jong ${ }^{39}$ y José Antonio Maravall ${ }^{40}$. Pero este último autor hace la observación de que el objeto designado por el nombre común quijote, aunque no hubiera desaparecido por completo, era de poco uso a principios del siglo XVII, y si los quijotes están casi fuera de la circulación, lógico es suponer que el sustantivo hubiera caído en desuso; es indicativo, al respecto, que en la novela nadie perciba en el nombre del caballero eco alguno del significado común de quijote, ni en sentido literal ni figurado, a pesar de que Cervantes no pierde ocasión de dar relieve a los aspectos grotescos del personaje. Por otro lado, poco tiene de extraño que el nombre del caballero no se asociara de manera inmediata con el nombre común quijote, dado que en la época no solo circulaba, según se ha documentado, el sobrenombre Quijote, sino también otros relacionados con sustantivos, adjetivos o verbos ${ }^{41}$.

En la elección del nombre del caballero se ha querido ver "una divertida combinación de tradiciones folklórico-literarias y de referencias históricas que remiten tanto al alegre mundo del Carnaval y de la locura como a las regocijadas variaciones onomásticas a que da lugar el habla de los moriscos" ${ }^{\prime 2}$. En esta línea de interpretación del nombre de don Quijote se sitúan los trabajos de Augustin Redondo y de Monique Joly ${ }^{43}$. Aunque no tiene ningún peso en

39. DoOREn, que entronca el nombre con los valores simbólicos que se habían atribuido a la armadura del caballero cristiano, llega a especificar que Cervantes podría aludir con el nombre de don Quijote a las obras de misericordia, siguiendo la exposición de BENOÎT DE CANFIELD en Le Chevalier Chrétien, según la cual el quijote derecho simboliza las obras espirituales y el izquierdo, las materiales (ELIE L. G. DEN DoOREN DE JONG: "Quijote, nombre significativo", Universidad: Revista de cultura y vida universitaria, XLIII, 1966, pp. 89-96). Esta afirmación apenas se sostiene si tenemos en cuenta que la obra se publicó en francés en 1609 (cuatro años después de la publicación del Quijote) y que su traducción castellana no vio la luz, con el título Regla de perfección, hasta 1629, trece años después de la muerte de Cervantes. No obstante, como señala DEN DOOREN, Cervantes no desconocería la asociación entre las piezas del arnés y la vida espiritual, de la que pudo informarse por variados caminos: Tirant lo Blanc, Erasmo o San Pablo.

40. J. A. MARAVALL identifica el sentido figurado del nombre común con una vaga asociación al esfuerzo y a la gloria de tiempos pasados: "El quijote pertenece a las armas del arnés que responde al esfuerzo personal. Don Quijote se rehace internamente y, claro está, socialmente a la par, por el uso de las armas antiguas. Y por eso escoge para llamarse a sí mismo la palabra con que se designa una de las piezas de la vieja y para él gloriosa armadura" (Utopía y contrautopía en el Quijote, Santiago de Compostela, Editorial Pico Sacro, 1976, p. 143).

41. C. LÁsCARIS ("El nombre de don Quijote", p. 362) menciona un Francisco Quijote. Y, sin salir del ámbito literario, podemos comprobar la frecuencia de esta clase de apellidos en casos como Ahumada, Herrera, Alemán, Acuña, Montemayor, etc.

42. Augustín Redondo, "El personaje de Don Quijote: Tradiciones folklórico-literarias, contexto histórico y elaboración cervantina", Nueva Revista de Filología Hispánica, XXIX (1980), pp. 3559; reproducido, con el título "El personaje de Don Quijote”, en Otra manera de leer el Quijote, Madrid, Castalia, 1997, pp. 205-230; la cita corresponde a la p. 230 de esta última edición. REDONDO asocia el personaje con una personificación de la cuaresma y explica el sentido del nombre del caballero manchego segmentándolo en Qui-xote, donde resonaría el significado del francés sot, del castellano zote y del italiano ciuto, adjetivos relacionados con la estupidez. El autor explica el paso de Quesada a Quijada-Quijano por efecto de la conversión de $s$ en la fricativa prepalatal sorda (representada $x$ en el texto), característica del habla de los moriscos.

43. La ocasión de que Cervantes adoptara este criterio carnavalesco para bautizar a su personaje vendría dada, según MoNiQue JoLY, por la permanencia en España, en los últimos años del siglo XVI, de la compañía del cómico italiano Alberto Naseli, conocido por el nombre de su máscara (Giovanni 
el mundo de don Quijote, no sería imposible que la asociación de su nombre con el carnaval y la locura formara parte del mundo de Cervantes. La sugerente propuesta de Joly y Redondo conduce a pensar en un autor que depositaría en el nombre de su personaje un cariz grotesco que, por lo demás, parece evidente para los primeros lectores de la obra, según testimonian las numerosas alusiones que se pueden espigar en las comedias de la época o en romances como el "Testamento de don Quijote", de Quevedo. Sin embargo, en estos casos el lado burlesco del personaje, muy acentuado, no aparece ligado a su nombre sino a sus malandanzas. Es verdad que Cervantes reitera continuamente la locura de don Quijote, pero también lo es que no faltan indicaciones que atenúan esa apreciación. Cabría la posibilidad de que, a medida que la narración va describiendo el hacerse de don Quijote, Cervantes fuera corrigiendo la carga burlesca que en el inicio pudiera haber depositado en su personaje; pero parece poco probable que haya tenido en cuenta estos matices carnavalescos en el nombre del caballero, pues el matiz burlesco -un aspecto muy parcial del ser de don Quijote - no da la verdadera medida de la talla del personaje ${ }^{44}$.

El erotismo presente en la obra cervantina ha recibido ${ }^{45}$ una atención que también ha dejado su huella en el sentido que se atribuye al nombre de don Quijote. En esta línea, Alfredo Baras Escolá se ha aplicado a las connotaciones sexuales escondidas en el nombre del andante manchego ${ }^{46}$. El erotis-

Ganassa), que alcanzó notoriedad encarnando al Arlequín de la commedia dell'arte. Piensa Joly que el nombre del hidalgo Quijada es calco de Ganassa (que significa 'mandíbula prominente') y que la variante Quesada se relaciona con queso, un atributo de los locos (MoniQuE JoLY, "D'Alberto Naseli, dit Gannasse, au comte de Benavente: deux notes cervantines" Bulletin Hispanique, LXXVIII, 1976, pp. 240-253, reproducido en Études sur Don Quichotte, París, Publications de la Sorbonne, 1996, pp. 13-27, de donde tomamos los datos).

44. Con todo, la propuesta de Joly, afianzada por Redondo, adolece de algunas limitaciones. Por un lado, el análisis del nombre Quijote no carece de incongruencias; nos preguntamos, sin hallar respuesta convincente, por las razones que llevan a conceder valor significativo a la parte final del nombre $(-x o t e=$ zote $)$ y se lo niegan a su parte inicial $(Q u i-)$. Por otro lado, tampoco vemos que haya correspondencia entre el empeño de justificar el trueque $s / x$ desde dentro del mundo textual (la condición morisca del traductor de Cide Hamete) y no se conceda mayor crédito a la información que literalmente se ofrece en el propio texto sobre el nombre del personaje.

45. Del asunto se han ocupado MoniQue Joly ("El erotismo en el Quijote. La voz femenina" y "Erotismo y marginación social en la novela cervantina", incluidos en Études sur Don Quichotte, París, Publications de la Sorbonne, 1996, pp. 163-180 y 181-194), Augustín REDONDo ("Las dos caras del erotismo en la primera parte del Quijote", en Otra manera de leer el Quijote, Madrid, Castalia, 1997, pp. 147-169), José RAMÓN FERNÁNDEZ DE CANO Y MARTín ("La destrucción del personaje en la obra cervantina: Andanzas y desventura del malogrado mozo de campo y plaza", Cervantes, 15.1, 1995, pp. 94-104, y "Del trasiego del trastrigo al trasero del teatro: Nuevas interpretaciones del vocabulario erótico cervantino", Cervantes, 19.2, 1999, pp. 87-100), y ALFREDo BARAS EsCOLÁ ("Una lectura erótica del Quijote", Cervantes, 12.2, 1992, pp. 79-89). Con diferente planteamiento estudia el tema Edgar Paiewonsky-Conde: "Cervantes y la teoría renacentista del deseo", Anales Cervantinos, XXIII (1985), pp. 71-81.

46. Alfredo Baras Escolá, "Una lectura erótica del Quijote", Cervantes, 12.2 (1992), pp. 7989. BARAS EsCOLÁ acepta que en el nombre está presente el significado del sustantivo común quijote, pero piensa que, lejos de su significado convencional, adquiere un sentido obsceno asociándose, por contigüidad, con el órgano sexual. De la misma manera, la terminación -ote (a la que da el sentido de 
mo subido de algunas situaciones descritas por Cervantes y el doble sentido de bastantes intervenciones de sus personajes son un hecho que no cabe negar. La presencia de la sexualidad en las obras de Cervantes cobra sentido en una concepción global de la vida, según la cual -creo- el trato sexual pone a prueba la consistencia moral de los individuos, de ahí su insistencia en este tema. El doble sentido de que a veces se carga la palabra del narrador o la de los personajes plantea, en el fondo, ese mismo problema tamizado por el de la incomprensión en la comunicación. Más discutible parece que las situaciones eróticas y los dobles sentidos respondan a una intención procaz, como se desprende de la interpretación del nombre que ahora estamos comentando; la supuesta alusión al órgano viril no resulta completamente ajena a la frecuente presencia de la sexualidad en Cervantes, pero resulta un tanto extraña por cuanto reduce el tratamiento de la sexualidad a su aspecto más superficial y, desde luego, recoge un aspecto poco o nada relevante de don Quijote.

La postulada filiación judaica de Cervantes ha llevado a tratar de explicar el significado del nombre de don Quijote desde modelos de tradición hebraica. En esta línea se sitúan Dominique Aubier y Ruth Reichelberg ${ }^{47}$. La plausibilidad de estas interpretaciones parece limitada por su propia disparidad y por el hecho de que es poco probable que Cervantes conociera la lengua de los hebreos aunque, como insinúa McGaha, pudo sentirse atraído (dada su curiosidad intelectual) por la mística judía en el cautiverio de Argel o bien por la supuesta ascendencia judía del autor; en todo caso, estas afirmaciones no

sufijo aumentativo) le permite asociar el nombre de don Quijote, por un lado, con varios sustantivos de idéntica terminación que designan el miembro viril y, por otro, con Lanzarote, en el que se incluye la secuencia lanza, palabra de equívocas connotaciones. A las supuestamente inequívocas alusiones obscenas del nombre del caballero, se añaden las del nombre del hidalgo (en Quij-ano "el sufijo comporta otra sugerencia a lo bajo corporal", p. 80), lo que aconsejaría, según BARAs Escolá, su eufemística omisión (que también se produce, por otra parte, en el capítulo final de la segunda parte) en la Licencia y en la Tasa, atribuida a muy distintas razones por FrANCISCO Rico ("El título del Quijote", Bulletin of Spanish Studies, LXXXI/4-5, 2004, pp. 541-551). También a eufemismo atribuye BARAS Escolá que Dorotea lo llame don Azote o don Gigote (I.30), pero no parece que esas denominaciones respondan a ningún pudor de Dorotea al tener que pronunciar el nombre del caballero; en el contexto de la intervención de Dorotea, esta simula haber olvidado el nombre de don Quijote a causa de que el olvido no disimulado de su propio nombre fingido (Micomicona), advertido por Sancho, ponía en peligro el engaño tramado para reducir al caballero.

47. AUBIER aprecia en el cambio de nombre un reflejo del cambio de personalidad que ya estaba presente en la tradición veterotestamentaria. Según AUBIER, la forma misma del nombre del caballero se relaciona con el arameo qeshot, que significa "verdad" o "certeza"; a mayor abundamiento, en Quijote está comprendida la secuencia ot, que en hebreo significa "signo", de donde se obtendría un significado global del nombre que, sobre poco más o menos, vendría a ser 'signo o anuncio de la verdad'; por otra parte, toma el nombre del hidalgo (Quijano) como anagrama de Anokhi, que corresponde al pronombre de la primera persona, 'yo'. A juicio de R. REICHELBERG, en el nombre del manchego se pone de relieve la locura del personaje, pues la autora pone en paralelo Quijote con el hebreo Ki shoteh, expresión que corresponde al significado de "loco". De las aportaciones de DominiQue AubIER (Don Quichotte, prophète d'Israël: essai, París, R. Laffont, 1966) y RuTH REICHELberg (Don Quichotte ou le roman d'un juif masqué, París, Seuil, 1999) da cuenta MichAEL McGAHA en "Is There a Hidden Jewish Meaning in Don Quixote?", Cervantes, 24.1 (2004), pp. 173-88. 
pasan, hoy por hoy, de ser suposiciones sin confirmación y, de ser ciertas, posiblemente nunca se confirmen ${ }^{48}$, dada la proscripción de la religión judaica. En todo caso, de corresponder el nombre de don Quijote a los significados que postulan Aubier y Reichelberg, no dejaría de tratarse de un sentido encriptado, accesible únicamente a quienes tuvieran conocimiento de la cultura y de la lengua hebraicas y completamente opaco para quienes no estuvieran al cabo de ellas. Dado que hasta el siglo XX no se ha abierto paso el matiz judaizante (ni en la propia novela ni en otros textos de la época se nos ofrecen evidencias que avalen la presencia de estas connotaciones en el nombre), no podemos tener la seguridad de que estuviera efectivamente presente en la intención con que Cervantes da nombre al protagonista de su obra.

\subsection{La patria del caballero: La Mancha}

También el añadido del nombre de la patria al del personaje tiene distinta validez para don Quijote, para los personajes que comparten con él el mundo novelesco y para Cervantes. Si el procedimiento seguido por don Quijote se atiene punto por punto al modelo onomástico de la caballería, es evidente que el sentido que le otorgan tanto el autor como algún personaje de la ficción está muy alejado de los supuestos del caballero manchego. El confesado propósito cervantino de desacreditar las ficciones caballerescas halla en el sobrenombre toponímico un paralelo formal con los nombres caballerescos tan cumplido como disparatado; como ha destacado Francisco García Pavón, la elección del sobrenombre "la Mancha" adquiere un marcado carácter paródico por inapropiado en el contexto caballeresco: "A ningún autor de auténticos libros de caballerías se le habría ocurrido situar a su héroe en una tierra monótona, apacible y civil, como a ningún autor de las actuales novelas policíacas se le ocurriría avecindar a sus hombres del F.B.I. en un villorrio de labrantines pacífi$\cos ^{49}$. Y en la misma dirección apunta el "grave eclesiástico" que acompaña a don Quijote en la mesa de los duques cuando espeta al caballero: “En dónde, nora tal, habéis vos hallado que hubo ni hay ahora caballeros andantes? ¿Dónde hay gigantes en España, o malandrines en la Mancha, ni Dulcineas encantadas, ni toda la caterva de las simplicidades que de vos se cuentan?" (II.31).

48. Cierto es que de las obras de Cervantes se desprende una reticente condena de la actitud de los cristianos viejos (en el Quijote, en La elección de los alcaldes de Daganzo, en el Retablo de las maravillas, etc.), lo cual no implica que hubiera de tener relación con conversos, sino, simplemente, que no hace suya tal postura excluyente.

49. Escribe GARCía PAVón: "Debía resultar enormemente chistoso el que un héroe, un caballero andante, llevase por sobrenombre el de una tierra nada famosa por sus hechos fantásticos, como era la Mancha, y con unos habitantes nada épicos, como sus labrantinos y aldeanos" ("La Mancha que vio Cervantes", Anales Cervantinos, IV, 1954, pp. 119-137; la cita en la p. 123). En el sentido paródico de la Mancha insiste F. SÁnchez Escribano, "Dos notas cervantinas", Anales Cervantinos, VIII (1959/1960), pp. 361-366. 
Más recientemente, los cervantistas han advertido otras connotaciones en el uso del topónimo como sobrenombre, las cuales podrían ser indicio de intenciones no explícitas en el texto. Estos sentidos secundarios no se refieren ya a la asociación entre el nombre del protagonista y el género caballeresco, sino a alguna propiedad del personaje o de su autor. Así, Howard Mancing, al tiempo que admite el sentido paródico, ve correspondencia entre el significado etimológico de la Mancha ("tierra seca") y la figura de don Quijote, hombre "seco de carnes" 50 . A juicio de Baras Escolá el sentido del sobrenombre toponímico está íntimamente relacionado con el sentido erótico que atribuye al nombre del caballero, de donde deduce que "otros valores alusivos deben posponerse a la infertilidad añadida, igual que un calificativo, al sentido erótico del nombre Quijote" 51 . Y Reichelberg, al hilo de la raíz hebrea que propone para el nombre de don Quijote, sostiene, apoyándose en el Tesoro de la lengua castellana, que la Mancha adquiere en la novela un doble sentido, el toponímico y, subrepticiamente, connota un negativo sentido social: el baldón que "estraga y desdora lo que de suyo era bueno, como mancha en un linaje" (Covarrubias). Si problemático es admitir el valor descriptivo de las connotaciones eróticas o judaizantes del nombre de don Quijote y apreciar en qué medida cobran validez en el texto, no lo es menos en el caso de la Mancha, dado que los estudiosos que postulan estas interpretaciones hacen depender el valor semántico del sobrenombre del que previamente habían adjudicado al nombre.

Desde el propio texto se justifica de manera indubitable el contenido pseudocaballeresco de la Mancha y su valor paródico se confirma en el desarrollo de la narración, pues, como bien advierte García Pavón (a quien seguimos en este punto), la ubicación de buena parte de la novela en tierras manchegas obedece a una selección guiada por un criterio que lleva a Cervantes a localizarla en un espacio anodino que le hace descartar la presencia de todo vestigio geográfico que tenga relación con hechos de relevancia histórica acaecidos en la región ${ }^{52}$. La Mancha, pues, no es un nombre de lugar sin más, sino también la imagen de un espacio narrativo, cuidadosamente elaborada a base de destacar cuanto lo acerca al mundo ordinario y de omitir cuanto lo relaciona con un pasado más a juego con el ideal caballeresco: un espacio, en fin, que contiene cuanto necesita el autor para subrayar la oportunidad (o inoportunidad) temporal y local del empeño de don Quijote.

50. Howard Mancing, "The Comic Function of Chivalric Names in Don Quixote", Names, XXI (1973), pp. 220-235; p. 222. Dorotea y Sansón Carrasco dicen que don Quijote es "seco de rostro"; a don Fernando le sorprende "su rostro de media legua de andadura, seco y amarillo"; y en el prólogo el autor se refiere al libro como un "hijo seco".

51. Alfredo Baras Escolá, "Una lectura erótica del Quijote”, p. 82.

52. "Para nada se habla en el Quijote de los muchos castillos grandes y famosos que hay en la Mancha; sí de ventas desvencijadas y archipobres. Para nada de calatravos, sanjuanistas, santiaguistas de honrosa ejecutoria otrora; y sí de villanos, arrieros, pastores y destripaterrones" (FRANCISCO GARCía PAVón, "La Mancha que vio Cervantes”, p. 123). 


\subsection{Significados en conflicto}

El examen de los sentidos asociativos que se han atribuido al nombre del caballero manchego arroja un heterogéneo balance en el que es preciso poner algún orden. Es imprescindible, ante todo, distinguir los aspectos connotativos destacados como tales en la novela de los que los cervantistas proyectan sobre el texto. Mediante las apreciaciones de diferentes personajes y los comentarios modalizadores de las distintas voces narradoras, Cervantes otorga relevancia suficiente a los matices satíricos que supone el uso de don como signo de distinción social y valor paródico inequívoco al añadido de la Mancha. Menos claro es que el nombre Quijote adquiera en el texto valores distintos del que, como nombre propio le corresponden; Cervantes no rehúye señalar esos valores asociados en el caso del tratamiento ni en el del topónimo, y parece difícil admitir que, de habérselos adjudicado, hubiera hecho otra cosa con el nombre del caballero, a pesar de que no renuncia a jugar con él cuando, siguiendo el juego de la dueña dolorida, Sancho Panza lo llama “don Quijotísimo" (II.38). Más bien don Quijote se presenta como nombre de significación recluida al ámbito de la voluntad del personaje que a sí mismo se lo ha puesto, mientras que para los demás (personajes, autor, lectores) viene a ser señal que lo singulariza, cerrada en su significación: es, simplemente, el nombre de alguien que así se llama.

Es imprescindible también distinguir entre nombre, personaje y autor. No hacerlo así ha llevado a atribuir al nombre algunos valores que, en caso de estar presentes en el texto, corresponderían a asociaciones relacionadas con el personaje o incluso con el autor más que con el nombre en sí mismo. La mayor parte de estas asociaciones, por otro lado, han emergido en los últimos cincuenta años, muy lejos ya del ambiente cultural en que se creó la obra, al hilo del desarrollo que han ido adquiriendo distintas hipótesis interpretativas sobre su significación cultural y sobre la figura de su autor; hasta tal punto es así que se han postulado, creo que forzadamente, connotaciones guiadas por estas hipótesis más que por el análisis del personaje o de su nombre.

Los valores connotativos del nombre del caballero nacen de confrontar diversos niveles de significación: el del sentido que le otorga el personaje, el que aprecian quienes comparten con él el mundo de la ficción y el que atañe a la comunicación entre autor y lector. Esos contenidos están simultáneamente presentes en el texto y se entrecruzan los unos con los otros. El conjunto está presidido por la visión del autor, que se mantiene diferenciada, aunque se acerca unas veces a la del protagonista y otras a la de los demás personajes; en la voz del narrador no se advierte estridencia alguna al anteponer don al nombre del caballero, pero no renuncia a mencionar la falta de legitimidad que aprecian otros personajes de la ficción y, mostrándola, traslada al lector su percepción de una costumbre vigente en su propio mundo histórico; con mayor sorna trata el sobrenombre de la Mancha, distanciándose del sentido que le da don Quijote, especialmente en pasajes como este: 'Este fin tuvo el Ingenioso Hidalgo de la Mancha, cuyo lugar no quiso poner Cide Hamete puntualmen- 
te, por dejar que todas las villas y lugares de la Mancha contendiesen entre sí por ahijársele y tenérsele por suyo, como contendieron las siete ciudades de Grecia por Homero" (II.74).

En cualquier caso, los juegos connotativos con el nombre del personaje no tienen una presencia permanente en el texto. Desempeñan, sin embargo, una importantísima función, por cuanto el autor se sirve de ellos para matizar, contrarrestar o invalidar los sentidos que le atribuyen sus criaturas. Cervantes señala de manera palpable la ocasión en que surge el conflicto de significados y marca cumplidamente las posiciones de las distintas voces que toman parte en él con objeto de que ni aquel ni estas pasen inadvertidas para el lector. La ambigüedad no es un valor cervantino y sí lo es la sutileza; los significados están perfectamente organizados en correspondencia con las voces que suenan en la novela; las piezas, bien dispuestas y las instrucciones, claras, como si del montaje de un mecanismo prefabricado se tratara; al lector le toca encajarlas en su sitio: no es cuestión de que falten o sobren piezas, sino de que cada una esté donde tiene que estar.

\section{Los apelativos: Caballero de la Triste Figura Y CABALLERO DE LOS LEONES}

En el transcurso de la narración, don Quijote adquiere dos nuevos nombres que acepta de buen grado. El primero, en la primera parte, se lo adjudica Sancho Panza cuando dice al bachiller Alonso López:

-Si acaso quisieren saber esos señores quién ha sido el valeroso que tales los puso, diráles vuestra merced que es el famoso don Quijote de la Mancha, que por otro nombre se llama el Caballero de la Triste Figura (I.19).

El segundo, en la segunda, se lo autoimpone don Quijote, rematada ya la aventura de los leones:

-Pues, si acaso Su Majestad preguntare quién la hizo, diréisle que el Caballero de los Leones, que de aquí adelante quiero que en este se trueque, cambie, vuelva y mude el que hasta aquí he tenido del Caballero de la Triste Figura (II.17).

El uso de estas nuevas fórmulas plantea algunos problemas sobre el valor de los nombres en la novela. Por una parte, el de discernir su valor denominativo; por otra, su valor representativo y, por último, el de su filiación caballeresca. 


\subsection{Valor denominativo de los apelativos}

Los dos nuevos nombres -Caballero de la Triste Figura y Caballero de los Leones- los toma don Quijote en calidad de nombres apelativos ${ }^{53}$. En las gramáticas de la época, nombre apelativo equivale a nombre común, distinto del nombre propio y opuesto a él en tanto que el nombre propio se aplica a un individuo y el común, o apelativo, a muchos, según Nebrija:

Proprio nombre es aquel que conviene a uno solo, como César, Pompeio. Común nombre es aquel que conviene a muchos particulares, que los latinos llaman apelativo, como ombre es común a 'César' y 'Pompeio'; ciudad a 'Sevilla' y 'Córdoba'; río, a 'Duero' y 'Guadiana' (Libro III, capítulo 2$)^{54}$.

El nombre propio se muestra notablemente diferente del apelativo. El nombre propio funciona como señal (en el sentido de Karl Bühler) para distinguir un individuo de otro; el apelativo, en principio, es símbolo que describe al individuo nombrado. Este puede utilizarse, como aquel, con la misma función singularizadora, pero a la singularización se llega por distinto camino en uno u otro caso. En el del nombre apelativo la singularización refleja lo nombrado verbalizando una propiedad que se percibe como inherente al individuo; en el caso del nombre propio la singularización se lleva a cabo conforme a una convención determinada, de una u otra forma, por la ascendencia del individuo. El apelativo nombra la propiedad; el propio, al individuo; este es un ser singular, mientras que la propiedad es una representación genérica y, para singularizar su referencia, es necesario que preceda el artículo. El nombre apelativo instaura una nueva convención complementaria de la operante en el caso de los nombres propios, pero no incompatible con ella. De hecho, en numero-

53. "El sabio, a cuyo cargo debe de estar el escribir la historia de mis hazañas, le habrá parecido que será bien que yo tome algún nombre apelativo", dice don Quijote a propósito de Caballero de la Triste Figura (I.19), y, a propósito de Caballero de los Leones, el narrador dice en la segunda parte: "Díjoles que se llamaba de nombre propio don Quijote de la Mancha, y por el apelativo, el Caballero de los Leones" (II.19).

54. Citamos la Gramática de Nebrija por la edición facsímil publicada por Espasa Calpe, Madrid, 1976, sin numeración de las páginas. La doctrina y la denominación nebrisense del nombre común como "nombre apelativo" se extiende a todo el siglo XVII. Así se aprecia en la exposición de GonZalo Correas (Arte de la lengua española castellana, edición y prólogo de Emilio Alarcos García, Madrid, CSIC, p. 156): "Apelativo o comun es el nombre general i universal que comprehende debaxo de si muchos particulares, como varon, muxer, ziudad, provinzia, rreino i otros tales. Varon comprehende a Diego, Xuan, Franzisco i los demás particulares. [...] Rreino comprehende todos los rreinos particulares chicos o grandes". Lo mismo puede decirse del Arte de la lengua española de JUAN VILLAR (Valencia, 1651, p. 4), donde consta: "El substantivo se divide en propio, y es el que significa cosas determinadas y ciertas (como Roma, Sevilla), y en apelativo, y es el que significa cosas indeterminadas y inciertas (como templo, plaça)". La Grammaire Generale et Raisonnée (1660, p. 35) también llama appellatifs a los nombres comunes ("ceux qui signifient les idées communes"). Todavía la primera gramática académica (Madrid, Ibarra, 1771, p. 4), aunque prefiere "común", alude al nombre "apelativo" ("Nombre común, que también llaman apelativo..."), denominación que ininterrumpidamente ha venido figurando en las diversas ediciones junto a la de "nombre común". 
sas ocasiones don Quijote se identifica con ambos nombres; Sancho nombra por primera vez al Caballero de la Triste Figura inmediatamente después de haber pronunciado el nombre de don Quijote de la Mancha, pero no se trata solo de establecer una ecuación explicativa fundacional, sino que de modo habitual el apelativo sigue al nombre propio en construcción explicativa: "Don Quijote de la Mancha, que un tiempo se llamó el Caballero de la Triste Figura y ahora se llama el Caballero de los Leones" (II.27).

Lo habitual es que el apelativo se utilice como explicación del nombre propio $^{55}$; es raro, sin embargo, que se designe al personaje con el apelativo únicamente, como en la carta de don Quijote a Dulcinea (I.25), y cuando tal cosa ocurre en el contexto comunicativo en que se nombra a don Quijote se tiene previo conocimiento de su nombre propio 56: "Digo que venga el señor Caballero de los Leones a un castillo mío que está aquí cerca" (II.30); cuando el duque denomina así a don Quijote ya está al tanto de quién es el personaje nombrado. Nunca, en cambio, se utiliza el nombre propio como explicación del apelativo en construcciones del tipo "El Caballero de la Triste Figura, por otro nombre don Quijote de la Mancha”, porque el contenido de una explicación debe ser una expresión derterminadora necesariamente más concreta y específica que la expresión determinada, y Caballero de la Triste Figura o Caballero de los Leones representan una información más concreta que la contenida en don Quijote.

\subsection{Valor representativo}

Los dos nombres apelativos que don Quijote adopta se igualan en que los asume de buen grado como imágenes de su propio ser, pero contrastan entre sí por el hecho de haber recibido el primero de Sancho Panza y de haberse impuesto el segundo por propia voluntad. Es indudable que este último (Caballero de los Leones) encuentra su motivación en la temeraria hazaña de desafiar al león; don Quijote busca la "gloriosa fama y duradera" en dar, de ese modo, testimonio de su valentía y así justifica su acción ante Diego de Miranda ${ }^{57}$.

55. Podrían, sin dificultad, acopiarse docenas de ejemplos como: "Don Quijote diría, señora, o, por otro nombre, el Caballero de la Triste Figura" (I.30); "Yo soy don Quijote de la Mancha, por otro nombre llamado el Caballero de la Triste Figura" (II.16); "Díjoles que se llamaba de nombre propio don Quijote de la Mancha, y por el apelativo, el Caballero de los Leones" (II.19); "Yo soy don Quijote de la Mancha, llamado el Caballero de los Leones por otro nombre" (II.29).

56. Esporádicamente la voz narradora designa a don Quijote únicamente mediante Caballero de la Triste Figura durante el tiempo que permanece en sierra Morena, pero nunca lo nombra únicamente con el apelativo Caballero de los Leones; este modo de dirigirse a don Quijote solo lo utilizan el duque y el fingido demonio que toma parte en el desfile que muestra a caballero y escudero el estado de la Dulcinea encantada (II.34).

57. Menos justificables son las connotaciones, rayanas en lo esotérico, que GraCIELA C. LAMANA DE LASA ("Enfoque estilístico de la nominación en el Quijote de Cervantes", Anales Cervantinos, XVI, 1977, pp. 139-158) atribuye a Caballero de los Leones. "Debemos tener en cuenta -dice- que al león le corresponde el color oro, símbolo de la culminación de un proceso ascendente" (p. 153); más ade- 
Más dudoso es que le cuadre de la misma manera lo de Caballero de la Triste Figura. Cuando Sancho lo llama así, inquirido por el caballero, el escudero le da la razón del nuevo nombre: "Porque le he estado mirando un rato a la luz de aquella hacha que lleva aquel malandante, y verdaderamente tiene vuestra merced la más mala figura, de poco acá, que jamás he visto" (I.19). En el apelativo, Sancho emplea el adjetivo triste con el mismo significado con que en la explicación emplea mala, que justifica por la desgarbada apariencia de don Quijote, y no sabe si atribuirla a la falta de fuerzas o a la falta de dientes ("débelo de haber causado, o ya el cansancio deste combate, o ya la falta de las muelas y dientes"); poco más adelante, habiendo don Quijote manifestado su intención de hacer pintar en su escudo "una muy triste figura", Sancho insiste en la voluntad designativa que lo ha guiado hasta el nuevo nombre:

\footnotetext{
-No hay para qué gastar tiempo y dineros en hacer esa figura - dijo Sancho-, sino lo que se ha de hacer es que vuestra merced descubra la suya y dé rostro a los que le miraren; que, sin más ni más, y sin otra imagen ni escudo, le llamarán el de la Triste Figura; y créame que le digo verdad, porque le prometo a vuestra merced, señor, y esto sea dicho en burlas, que le hace tan mala cara la hambre y la falta de las muelas, que, como ya tengo dicho, se podrá muy bien escusar la triste pintura (I.19).
}

En triste figura (= mala figura, mala cara), Sancho está representando cómo percibe visualmente al caballero y con el adjetivo da relieve a la falta de gallardía que observa en don Quijote.

Pero el sentido de triste no es el mismo para don Quijote. El caballero hace suyo de buena gana el apelativo por entender que el adjetivo se refiere a la aflicción del ánimo que le causa el amor a Dulcinea. Con "El caballero de la Triste Figura" como única firma dirige una carta de amores -que Sancho nunca entregaría- a la señora de sus pensamientos, en la que aflora la medida de su tristeza en expresiones como "El ferido de punta de ausencia y el llagado de las telas del corazón" (I.25); en la áspera penitencia de Sierra Morena no deja de escribir versos "acomodados a su tristeza" (I.26); "Mira no me engañes -dice a Sancho cuando le anuncia la llegada de su dama-, ni quieras con falsas alegrías alegrar mis verdaderas tristezas" (II.10); y Sancho trata de sacarlo del abatimiento en que lo ha postrado el encantamiento de Dulcinea diciéndole: "Señor, las tristezas no se hicieron para las bestias, sino para los hombres" (II.11).

El equívoco es evidente: Don Quijote interpreta triste en referencia a un estado interno; Sancho lo utiliza como referente de la apariencia exterior ${ }^{58}$. En

lante relaciona el símbolo astrológico del león con la casa del sol (p. 154) y, en su opinión, la derrota del Caballero de los Leones ante el de la Blanca Luna (símbolo a su vez de Isis), representa "la fiesta del comienzo anual de las navegaciones" (p. 156).

58. Se ocupan de estos significados y de su traducción en las versiones inglesas de la obra P. E. Russell ("Don Quixote as a Funny Book", Modern Language Review, LXIV/2, 1969, pp. 312-326; concretamente en las pp. 316-317), y A. G. Lo RÉ ("A reply to P. E. Russell's comments on the expression El Caballero de la Triste Figura”, Cervantes, 8.2, 1988, pp. 225-30); véase también el co- 
boca de don Quijote el apelativo está preñado de matices serios; Sancho destaca su lado cómico deformándolo algunas veces ${ }^{59} \mathrm{o}$ insistiendo otras en el sentido que él había dado al nuevo nombre ${ }^{60}$ y la voz del narrador fluctúa, aproximándose de vez en cuando al sentido sanchopancesco del apelativo ${ }^{61}$. Con intención jocosa, Cervantes hace confluir en una misma forma sentidos distintos y hasta opuestos, que, en el fondo, dan cuerpo en esta ocasión a uno de los problemas que con mayor frecuencia asoman a su obra: las relaciones entre el ser y el parecer.

En la distancia que separa el ser del parecer sustenta Atlee su interpretación del apelativo como una censura implícita de la Contrarreforma. Atlee cree que en la expresión Caballero de la Triste Figura el sustantivo figura cobra un sentido simbólico relativo al "orden y la interpretación descriptiva de los acontecimientos y de los hechos dignos de memoria"; según este autor, $f i$ gura vendría a codificar la atmósfera de intolerancia religiosa de la España de Cervantes (el ser, según Atlee) a la que no puede aludirse sino mediante rodeos expresivos (el parecer) impuestos por una cuidadosa autocensura ${ }^{62}$. Atlee trata de confirmar una hipótesis enraizada en la sugestiva visión que Américo Castro tiene de Cervantes, pero los datos que maneja se avienen mal con su propósito, pues no tiene en cuenta que el significado de figura es el usual en la lengua del momento ("Vale talle, parecer, semejanza", dice Covarrubias) y que en ninguno de los contextos en que se utiliza el apelativo se sugiere un sentido distinto. En consecuencia, su idea es más que discutible, ya que, como tantas otras, parte más de lo que se ha dicho sobre Cervantes que de lo que el mismo Cervantes dice en su obra.

mentario de Edwin WiLliamson (Don Quijote de la Mancha. Volumen complementario, edición dirigida por FrancisCo Rico, Barcelona, Crítica, 1998, p. 57).

59. En una ocasión Sancho llama a don Quijote "señor Triste Figura" (I.37), cuando siente que se esfuma la oportunidad de ganar sustanciosa recompensa tras oír que los personajes de la venta llaman Dorotea a la que caballero y escudero creían princesa Micomicona, y en otra ocasión corrige al duque en su modo de dirigirse a don Quijote: "-... Venga el gran Caballero de la Triste Figura.... -De los Leones ha de decir vuestra alteza -dijo Sancho-, que ya no hay Triste Figura, ni figuro" (II.30).

60. Fingidamente vuelto del Toboso, Sancho da cuenta a don Quijote del efecto chistoso que supone que el apelativo habría de causar en Aldonza Lorenzo: "Rióse mucho cuando le dije cómo se llamaba vuestra merced el Caballero de la Triste Figura" (I.31)

61. Como, por ejemplo, en el momento en que se encuentran don Quijote y Cardenio el narrador llama a este -todavía innombrado- "el Roto de la Mala Figura, como a don Quijote el de la Triste" (I.23), poniendo en evidente paralelo las confluencias entre ambos personajes.

62. En su artículo "En torno a una frase del Quijote: El Caballero de la Triste Figura" (Anales Cervantinos, XX, 1982, pp. 49-57), Michael A. F. ATLEe expone esta particular interpretación del apelativo, que relaciona con la batalla de los rebaños, ocasión que da motivo a la descompuesta figura de don Quijote. Puesto que para el caballero los rebaños representan sendos ejércitos, cristiano uno y musulmán el otro, don Quijote interviene en ayuda de los cristianos, lo que le acarrea las sabidas consecuencias de un nuevo molimiento y la pérdida de varias piezas dentales. El malparado estado en que queda don Quijote lo interpreta ATLEE como una especie de castigo de Cervantes a su personaje, pues, según él, don Quijote hace suyo un cristianismo militante cuyo horizonte es "hacer guerras, matar en nombre de Dios" (p. 56). De ese modo, Cervantes habría acudido al apelativo Triste Figura para expresar, de manera encubierta, su rechazo de la ideología contrarreformista. 


\title{
5.3. Apelativos y caballería
}

No contento con la explicación que Sancho da de la motivación del apelativo Caballero de la Triste Figura, don Quijote la atribuye a causas bien distintas:

\begin{abstract}
-No es eso -respondió don Quijote-, sino que el sabio, a cuyo cargo debe de estar el escribir la historia de mis hazañas, le habrá parecido que será bien que yo tome algún nombre apelativo, como lo tomaban todos los caballeros pasados: cuál se llamaba el de la Ardiente Espada; cuál, el del Unicornio; aquel, de las Doncellas; aqueste, el del Ave Fénix; el otro, el Caballero del Grifo; estotro, el de la Muerte; y por estos nombres e insignias eran conocidos por toda la redondez de la tierra. Y así, digo que el sabio ya dicho te habrá puesto en la lengua y en el pensamiento ahora que me llamases el Caballero de la Triste Figura, como pienso llamarme desde hoy en adelante.
\end{abstract}

Don Quijote acepta el apelativo porque "lo tomaban todos los caballeros pasados"; y otro tanto sucede con Caballero de los Leones: "En esto sigo -dice don Quijote- la antigua usanza de los andantes caballeros, que se mudaban los nombres cuando querían, o cuando les venía a cuento" (II.17). El caballero manchego emula el modelo caballeresco que ya había adoptado como criterio para llamarse don Quijote de la Mancha. Don Quijote se sitúa en parangón con otros caballeros andantes que habían mudado de nombre; Deocliano había hecho suyo el nombre de Caballero de la Triste Figura ${ }^{63}$; en el punto en que don Quijote se dispone a penetrar en la jaula del león, Cide Hamete lo califica de "segundo y nuevo don Manuel de León, que fue gloria y honra de los españoles caballeros" ${ }^{4}$, a lo que se añade que en el capítulo undécimo del primer libro de Amadís de Gaula, este, arreado con armas de leones, arma caballero a su hermano Galaor.

Como Mancing subraya, la perseverancia de los criterios nominadores propios del género caballeresco responde a una intención paródica que, en el caso de los apelativos, halla continuidad en el plan cervantino, intensificada con los equívocos matices que cobra Caballero de la Triste Figura en las voces de los distintos personajes y en la del narrador. Nada añaden las pretendidas connotaciones simbólicas; Cervantes no juega a encriptar sus afirmaciones, sino a dejar palpable muestra (semiescondida a veces, pero accesible) de la consideración que le merece el modelo narrativo caballeresco. En la utilización de los apelativos, los matices paródicos cobran mayor relieve que su relación con la identidad del personaje, pero no la anulan. Los nombres apelativos se muestran como identificación insuficiente, de donde nace su espo-

63. Se trata de un personaje de Clarián de Landanís (véase la edición de Luis Andrés Murillo, Madrid, Castalia, 1973, vol. I, p. 235, nota 18). HowARD MANCING añade a esta serie el nombre de Caballero de la Rica Figura, que toma don Belianís de Grecia ("The Comic Function of Chivalric Names in Don Quijote", p. 222).

64. Mancing ("The Comic Function of Chivalric Names in Don Quijote", p. 222) menciona tres casos de caballeros andantes que adoptan del León o de los Leones como apelativo. 
rádica utilización. Los apelativos individualizan al personaje verbalizando un aspecto parcial del ser personal, demasiado reducido para encerrar la totalidad de su singularidad, mientras que don Quijote lo singulariza de una manera más abarcadora, más apropiada para señalar su individualidad. Por eso, los apelativos son nombres inestables hasta cierto punto, pues pueden suprimirse sin merma de la individualización del personaje (basta llamarlo don Quijote, sin necesidad de añadir los apelativos) y, de hecho, se adjuntan a don Quijote temporalmente: la primera mención de don Quijote como Caballero de la Triste Figura tiene lugar en el capítulo 19 de la primera parte y la última, en el 30 de la segunda; y Caballero de los Leones se extiende entre los capítulos 17 y 34 de la segunda parte.

\section{Alonso QuiJano}

En el capítulo final de la segunda parte de la obra, en trance de muerte, el personaje emprende la última y definitiva transmutación onomástica, inversa a la del capítulo inicial de la primera parte. Inmediatamente antes del nuevo cambio de nombre, se producen en el personaje otros cambios, también en sentido inverso a los iniciales: el paso de la locura a la cordura y la abominación de las lecturas caballerescas ("Yo tengo juicio ya, libre y claro, sin las sombras caliginosas de la ignorancia, que sobre él me pusieron mi amarga y continua leyenda de los detestables libros de las caballerías", II.74). Después de mandar llamar al cura, al barbero y a Sansón Carrasco, revela su verdadero nombre: "Ya yo no soy don Quijote de la Mancha, sino Alonso Quijano, a quien mis costumbres me dieron renombre de Bueno". En ese momento, el personaje se percibe a sí mismo de manera diferente de como se había percibido a lo largo de la narración. Es su propia voz, y no la del narrador, la que transmite el acabamiento del proceso completo. Pero, por debajo de los nuevos cambios, de la misma manera que en el paso del nombre del hidalgo al de caballero, ahora, en el de caballero a hidalgo persiste la secuencia fónica Quij, sobre la que se mantiene la similitud del nombre en las tres etapas de la andadura del personaje; en ella se concreta un nexo, nunca roto, que aglutina las distintas facetas del gris hidalgo cuerdo, el fantasioso caballero loco y el juicioso hombre que ya se dispone a morir.

Sin embargo, sin invalidarse esa esencial continuidad, se producen modificaciones muy notorias, las cuales no reconducen la situación a su estado inicial, sino a un punto muy diferente. En primer lugar, es diferente el modo de producirse la transformación del personaje; aunque Fernando Torres Antoñanzas habla de una "noche oscura de don Quijote", que abarca desde la derrota en Barcelona hasta la muerte, como momento de crisis que anticiparía gradualmente la transformación final en Alonso Quijano ${ }^{65}$, lo cierto es que en

65. Fernando Torres Antoñanzas, Don Quijote y el absoluto. Algunos aspectos teológicos de la obra de Cervantes, Salamanca, Universidad Pontificia, 1998, especialmente pp. 378-385. 
esos capítulos don Quijote sigue siendo don Quijote, un don Quijote hundido en el desengaño. El cambio le sobreviene al personaje de manera súbita, como una revelación motivada por la inminencia de la muerte, mientras que la inmersión en don Quijote, rápidamente relatada en el primer capítulo, se había ido produciendo de manera gradual, al compás de la lectura de libros de caballerías. Distinto es también el papel que a la voluntad le corresponde en esta transformación final; en la que había llevado desde el hidalgo a don Quijote la voluntad había sido la causa desencadenante, mientras que ahora la voluntad no interviene en la transformación misma; la voluntad entra en juego de otra manera: asintiendo al cambio que se ha producido. No hay resignación en Alonso Quijano, sino aceptación activa de su nueva situación, aceptación que integra en su vivencia actual sus vivencias pasadas.

En segundo lugar, el nombre Alonso Quijano disipa la vaguedad (Quijada, Quesada, Quijana) de la identificación inicial; a aquellas irónicas imprecisiones se contrapone ahora la forma inequívoca Quijano, varias veces repetida en el capítulo y confirmada por la forma feminizada aplicada a la sobrina (Antonia Quijana), lo cual no es infrecuente en la época. MacCurdy y Rodríguez señalan que la fijeza final del nombre del hidalgo es un instrumento de desrelativización 66 , pues como dice Guillén, en el momento de la muerte "ya no cabe la conjetura irónica sobre el nombre del hidalgo"67.

En tercer lugar, aparece por vez primera el nombre de pila (Alonso); el sobrenombre, único dato sobre el hidalgo que se aportaba en el capítulo inicial, indica la pertenencia del individuo a su linaje, pero no es suficiente para distinguirlo de otros individuos también pertenecientes a ese grupo familiar; esa función está encomendada al nombre de pila, en el que se concreta la individualización del personaje.

En cuarto lugar, el nombre aparece pronunciado de labios del hidalgo. Esta es la definitiva y auténtica razón de su desrelativización, usando el término de MacCurdy y Rodríguez; no lo desrelativiza tanto la sustitución de la multiplicidad inicial por la fijeza del único nombre final, cuanto la distinción entre lo que al principio no era sino una posibilidad de identificación y lo que ahora es inequívoca certeza. La información que proporciona la voz de Alonso Quijano sitúa cada perspectiva en el lugar que le cumple: la de los supuestos historiadores del principio (tan lejanos del personaje como ajenos a él), como incierta expectativa, y la seguridad del personaje, como autoridad incontrovertible para la fijación; la propia voz de Alonso Quijano no solo se constituye en garantía de la autenticidad de su nombre, sino que también desautoriza las voces de quienes elaboraban "conjeturas verosímiles" sobre él; a lo verosímil se contrapone lo verdadero y a la perspectiva externa, la interna.

66. Raymond MacCurdy y Alfred Rodríguez, "Algo más sobre los apellidos verdaderos de don Quijote”, Romanische Forschungen, XC (1978), pp. 448-457; p. 455.

67. Jorge GuILlén, "Vida y muerte de Alonso Quijano", Romanische Forschungen, LXIV (1952), pp. 102-113; las palabras citadas, en la p. 109. 
Y, en quinto lugar, aparece también por vez primera el apelativo el Bueno, un procedimiento paralelo al de nominaciones como Caballero de la Triste Figura o Caballero de los Leones, que don Quijote se había otorgado; el apelativo se repite dos veces en boca de Alonso Quijano, otra en la del cura y dos más en la voz del narrador; como se ha visto en el caso de los apelativos del caballero, el apodo significa un atributo de la persona que puede llegar a singularizar recategorizándose en antropónimo.

Es precisamente este atributo del personaje encerrado en la expresión el Bueno el que encarna el nexo entre la identidad del hidalgo Alonso Quijano y la del caballero don Quijote. El hidalgo rechaza identificarse con el nombre del caballero: renuncia a don y a de la Mancha como reniega de los excesos caballerescos; pero eso no supone ruptura de la identidad, pues, al margen de que en el nombre se mantenga la secuencia que asegura la continuidad (Quij), en el personaje -llámese Alonso Quijano o don Quijote- hay un rasgo que, por encima de la diversidad de nombres, vincula su identidad al juicio moral que merece su comportamiento. Así lo percibe el narrador:

En tanto que don Quijote fue Alonso Quijano el Bueno, a secas, y en tanto que fue don Quijote de la Mancha, fue siempre de apacible condición y de agradable trato, y por esto no solo era bien querido de los de su casa, sino de todos cuantos le conocían.

El hidalgo no se reconoce como don Quijote, pero se reconoce en don Quijote. En esta cita, como en todo el capítulo, puede comprobarse que el narrador identifica a su personaje con la expresión don Quijote, incluso después de haberse revelado como Alonso Quijano; la voz narradora parece otorgarle la parte más definitoria de la identidad única, mientras que sus nombres (Alonso Quijano y don Quijote de la Mancha) constituyen variantes que remiten a un núcleo único de identidad sustentado sobre un principio moral, como en el caso de Segismundo en La vida es sueño: "Sea verdad o sueño, / obrar bien es lo que importa". En don Quijote se reconoce Alonso Quijano a sí mismo cuando en la primera de las mandas de su testamento se refiere a Sancho Panza:

Si como estando yo loco fui parte para darle el gobierno de la ínsula, pudiera agora, estando cuerdo, darle el de un reino, se le diera, porque la sencillez de su condición y fidelidad de su trato lo merece.

En la propia palabra de Alonso Quijano, el paso de la locura a la cordura lejos de invalidar los actos pasados del loco ("fui parte para darle el gobierno de la ínsula") los revalida y aun los intensifica ("agora... darle el de un reino") el cuerdo en el presente. Sobre distintos estadios temporales y diferentes grados de lucidez prevalece la continuidad de una identidad moral generadora de actos emanados de una misma voluntad. En el momento supremo, aun cuando abomine de lo accidental, el cuerdo se reconoce esencialmente en el loco tanto como en sus andantes correrías el loco se reconocía en el cuerdo y fantasioso hidalgo del inicio. 
Así lo perciben cuantos rodean a don Quijote en su lecho de muerte, quienes no terminan de aceptar que haya distinción entre caballero andante e hidalgo de a pie; al antiguo empeño de disuadir al caballero de sus temerarias hazañas, se contrapone cierta resistencia del cura, del barbero y del bachiller Carrasco a admitir su transformación en pacífico hidalgo; Sancho lo invita a resucitar la Arcadia y asume la culpa de la derrota del caballero; el escribano presente en el momento de la muerte del personaje no tiene conciencia de haber visto morir al hidalgo, sino a don Quijote ("Hallóse el escribano presente, y dijo que nunca había leído en ningún libro de caballerías que algún caballero andante hubiese muerto en su lecho tan sosegadamente y tan cristiano como don Quijote"), y tampoco para el cura constituyen antinomia los dos nombres del personaje:

Viendo lo cual el cura pidió al escribano le diese por testimonio como Alonso Quijano el Bueno, llamado comúnmente don Quijote de la Mancha, había pasado desta presente vida y muerto naturalmente.

Al concluir la narración, el capítulo final retoma, con diferente perspectiva, el planteamiento del capítulo inicial: las dos facetas de la identidad de don Quijote. Pero no para restaurar el orden previo al arranque de la novela. El Quijote no es un viaje de ida y vuelta desde la cordura a la locura y a la inversa; no hay vuelta: el curso de la historia lleva a un final distinto del comienzo; entre el hidalgo del capítulo inicial y el del capítulo final media la trayectoria de don Quijote, y esta no se ha producido en vano; no se trata de restaurar nada; la idea moderna de la sucesión del tiempo, la conciencia de la propia individualidad, el afán de trascendencia y el concepto de la existencia como leal compromiso con lo que el hombre debe a otro y se debe a sí mismo conducen a una síntesis de orden superior en que se resuelve la oposición del principio.

Establecer en qué consiste, sustancialmente, esta síntesis final exige retrotraerse a la idea, postulada por Torrente Ballester y Castilla del Pino, de que don Quijote es una creación del hidalgo manchego, un personaje suyo. Y lo es hasta el punto de cobrar una prominencia tan desmedida que se sobrepone al actor en que se encarna, amenazando con anularlo, como Juan Rana se sobrepone a Cosme Pérez, Charlot a Charles Chaplin o Cantinflas a Mario Moreno; Jorge Guillén lo aprecia con justeza cuando afirma que si bien el hidalgo permanece siempre en su personaje, "se limita a ser el hermano menor de don Quijote, el aspecto más humilde de su figura"68. De la misma manera, en lo más hondo de la conciencia de Sancho, del barbero, de Sansón Carrasco, del cura y del escribano, según se ha visto, la figura de don Quijote pesa tanto o más que la de su convencino Alonso Quijano. Y en su lecho de muerte, Alonso Quijano aprecia en los excesos de don Quijote una máscara que amenaza con disgregarse de su propia identidad confesando a su sobrina:

68. JoRGE GuILLÉn, "Vida y muerte de Alonso Quijano", p. 103 
Yo me siento, sobrina, a punto de muerte; querría hacerla de tal modo, que diese a entender que no había sido mi vida tan mala que dejase renombre de loco, que, puesto que lo he sido, no querría confirmar esta verdad en mi muerte.

A punto de segmentarse del hombre que lo creó, don Quijote es insostenible desde la conciencia del hidalgo sin riesgo de pasar a ser otro. El reto de ganar la identidad consiste en hacerse a sí mismo, no en hacerse otro, y al recuperar el juicio y el nombre, aceptándose en lo que es y depurando lo que ha sido, Alonso Quijano redime de la mediocridad al hidalgo del principio y de la locura al caballero andante: integra a ambos y se constituye en superación suya culminando la tarea de hacerse y cerrando el paso a la disolución. Renuncia ahora a vivirse como correlato de una narración fantasiosa, en oposición a su confesado deseo de serlo cuando sale al campo por primera vez:

¿Quién duda sino que en los venideros tiempos, cuando salga a luz la verdadera historia de mis famosos hechos, que el sabio que los escribiere no ponga, cuando llegue a contar esta mi primera salida tan de mañana, desta manera?: "Apenas había el rubicundo Apolo tendido por la faz de la ancha y espaciosa tierra las doradas hebras de sus hermosos cabellos, y apenas los pequeños y pintados pajarillos con sus arpadas lenguas habían saludado con dulce y meliflua armonía la venida de la rosada aurora, que, dejando la blanda cama del celoso marido, por las puertas y balcones del manchego horizonte a los mortales se mostraba, cuando el famoso caballero don Quijote de la Mancha, dejando las ociosas plumas, subió sobre su famoso caballo Rocinante, y comenzó a caminar por el antiguo y conocido campo de Montiel" (I.2).

No se eleva, como se elevaba el hidalgo primigenio, aspirando a convertirse, por la fuerza de su brazo, en materia digna de relación caballeresca. Tampoco aspira ya a revivir, como había previsto poco antes, la Arcadia en la Mancha ${ }^{69}$; por eso desecha prolongar la vida de su máscara con el proyecto pastoril que le recuerda Sansón Carrasco: “¿Agora que estamos tan a pique de ser pastores, para pasar cantando la vida, como unos príncipes, quiere vuesa merced hacerse ermitaño? Calle, por su vida, vuelva en sí, y déjese de cuentos". La respuesta de Alonso Quijano ("Déjense burlas aparte") deja bien a las claras que el pastor Quijotiz (en cuyo nombre vuelve a aparecer Quij- como sustrato básico que mantiene la continuidad) no llegará a nacer porque quien debía encarnarlo siente la máscara del héroe literario demasiado estrecha para

69. "Yo compraré algunas ovejas, y todas las demás cosas que al pastoral ejercicio son necesarias, y llamándome yo el pastor Quijotiz, y tú el pastor Pancino, nos andaremos por los montes, por las selvas y por los prados, cantando aquí, endechando allí, bebiendo de los líquidos cristales de las fuentes, o ya de los limpios arroyuelos, o de los caudalosos ríos" (II.67). “...Lo más principal de aquel negocio estaba hecho, porque les tenía puestos los nombres, que les vendrían como de molde. Díjole el cura que los dijese. Respondió don Quijote que él se había de llamar el pastor Quijotiz; y el bachiller, el pastor Carrascón; y el cura, el pastor Curambro; y Sancho Panza, el pastor Pancino" (II.73). 
encerrar su experiencia. El hidalgo del capítulo inicial escapaba de la vida literarizándose; Alonso Quijano entiende que la literatura es insuficiente, aunque no inútil (los desvaríos de don Quijote "los ha de volver mi muerte, con ayuda del cielo, en mi provecho", dice el personaje), que la hazaña suprema del hombre es vivir con dignidad y que la dignidad está tan al alcance del vencedor como del vencido. Conquistar la dignidad es no negarse y en ese empeño está el Alonso Quijano del capítulo final.

\section{CONCLuSiOnes}

A lo largo de la novela, el curso que siguen los nombres que se adjudican al personaje central transcurre paralelo al de las modulaciones que adquiere su identidad, considerada esta como el núcleo mental desde el que se vive. La identidad tiene una dimensión esencialmente interna, pero también se proyecta hacia fuera; el individuo (en nuestro caso el personaje) toma continuamente decisiones acerca de la constitución de su ser íntimo y de las relaciones que ha de mantener con el mundo; desde la identidad piensa, siente, hace y dice, esto es, vive haciéndose a sí mismo. Para Cervantes, el norte del hacerse es la búsqueda de la singularidad de cada cual: "Sábete, Sancho, que no es un hombre más que otro si no hace más que otro", dice don Quijote (I.18) y es al individuo a quien compete tomar las decisiones fundamentales sobre su propia vida: "Cada uno es artífice de su ventura". Ya se ha hecho mención de cómo el hidalgo manchego llega a hacerse don Quijote rechazando un concepto de identidad enraizado en lo social más que en lo personal; hasta ese momento, la identidad residía en un ámbito de la realidad que puede calificarse de histórico, de dato históricamente verificable, pero desde ese momento pasa a residir en un ámbito moral, como se evidencia en las palabras de don Quijote a Pedro Alonso ("Sé quién soy; y sé que puedo ser...") y reitera el propio personaje en su lecho de muerte. Concebida como hecho histórico, la identidad es algo estático, inmodificable; como aspiración moral es en cambio, dinámica, sin llegar a perder la estabilidad que le presta el emanar de la conciencia del individuo.

La relación entre nombre e identidad del personaje central del Quijote pasa por tres fases bien diferenciadas. En la primera tenemos un hombre de identidad amorfa e identificación problemática; el personaje posee la identidad heredada de un pasado narrativo que se ha fraguado entre bastidores y se intuye dentro de él una confusión que indudablemente impera, fuera de él, en quien trata de identificarlo por su nombre. A la segunda fase, la de don Quijote, llega el hidalgo por la voluntad de afirmarse como otra cosa distinta de la que había sido hasta ese momento; llega así a forjar una criatura que posee la identidad deseada y a quien se identifica de manera inequívoca (siempre como don Quijote), aunque variable en sus apelativos; la voluntad de ser se proyecta ahora hacia el futuro. En la tercera fase, la de Alonso Quijano, este es hombre de identidad aceptada e identificación inequívoca y estable en su verdadero nom- 
bre; la aceptación de la identidad por Alonso Quijano implica reconocerse en lo presente asumiendo lo pasado como parte del propio ser para encarar el corto pero decisivo futuro que lo lleva a la muerte.

El conjunto de los distintos nombres del personaje dista de ser un montón desordenado; por el contrario, está hábilmente organizado en relación con la crítica, confesada por el propio autor, de la novela caballeresca. Solo el nombre de don Quijote de la Mancha se atiene al molde onomástico propio de ese tipo de narraciones. Pero Cervantes toma solo el modelo: los aspectos satíricos focalizados en don y lo grotesco del añadido la Mancha, expresamente señalados en la novela, son claro indicio de que el autor contempla con distancia burlesca ese modo de bautizar a los personajes. Solo don Quijote cree en las resonancias caballerescas de su nombre, pero no los demás personajes; quienes lo conocían antes de nombrarse de esa manera le siguen el juego con el propósito de deshacer su ilusión, quienes no lo conocían toman el nombre como cualquier otro nombre y no lo reconocen por él como caballero, aunque no dejen de admirarse de sus dichos y sus hechos, y quienes sin conocerlo previamente están al cabo de sus manías subrayan la falta de proporción entre el nombre adoptado y el modelo que sigue, como es el caso del eclesiástico que reprende a los duques.

El nombre del caballero, en su relación con los nombres caballerescos, entra también en confrontación con el del hidalgo. El nombre de don Quijote nace de la necesidad de encontrar denominación que esté en correspondencia con haber mudado de estado. En el momento inicial percibe esa asociación entre el nombre y el ser, cercana a la doctrina de los nombres expuesta por fray Luis de León, según la cual hay una vinculación natural entre el significado y el ser. Sin embargo, los nombres muestran también la particular visión con que cada cual representa las cosas; sobre esta idea descansa la interpretación planteada por Spitzer, y puntualizada por $\operatorname{Read}^{70}$, de que la variedad onomástica del Quijote no es sino reflejo de una realidad cambiante en sus perfiles; por otra parte, el mismo Spitzer dice que "en cuanto moralista, Cervantes no es en absoluto perspectivista", afirmación que se aviene mal con la tesis central de su ensayo. Y, sin embargo, es verdad que el perspectivismo está presente en el Quijote aunque no sea esa la posición vital de Cervantes; el punto en que confluye esa disparidad lo resuelve la ordenación de los distintos nombres en el mundo representado en la novela. Cervantes recurre al conflicto de perspectivas para mostrar las limitaciones de estas, pero no acepta que la realidad, aunque susceptible de ser representada, se reduzca a su mera representación. Haciendo a Alonso Quijano pronunciar su propio nombre y tomar la decisión de aceptarse en el hidalgo y en el caballero que fue un tiempo, muestra que la esencia de la identidad no es cuestión de nombres, sino que está enraizada en un estrato más profundo. Ya hemos mencionado que MacCurdy y Rodríguez subrayan cómo se diluye el perspectivismo onomástico en el capítulo final y

70. Malcolm K. Read, "Language Adrift: A Re-appraisal of the Theme of Linguistic Perspectivism in Don Quijote”, Forum for Modern Language Studies, 17.3 (1981), pp. 271-287. 
que la voz de Alonso Quijano pone orden en un desordenado -hasta ese momento- conjunto de nombres. Spitzer se limitó a constatar la multiplicidad de los nombres sin advertir que la unidad subyace a la variedad, y que a esa unidad se llega buscando la organización estructural del conjunto denominador.

Los nombres del personaje no son un grupo variopinto; están organizados desde el de Alonso Quijano y por su relación con este nombre cobran su sentido todos los demás. Alonso Quijano es el verdadero nombre del hombre identificado, sucesivamente, como Quijada, Quesada, Quejana, Quijana y don Quijote (con sus correspondientes variaciones Caballero de la Triste Figura, Caballero de los Leones y la nonata Quijotiz); lo constitutivo de la identidad del personaje preexiste a sus identificaciones y es independiente de ellas: el hombre se define por su ser, no por su nombre. El juego de nombres se va tejiendo a lo largo de la novela sobre la falsa ecuación de que identidad e identificación son la misma cosa, pero la identidad radica en el ser del individuo, mientras que la identificación consiste en nombrar mostrando el conocimiento del ser. Solo al final se muestra la identificación auténtica, la que Alonso Quijano reconoce, y entonces todos los demás nombres se revelan como falsificaciones: el de don Quijote de la Mancha, por ilusoria máscara de un hombre de buena voluntad; los del capítulo inicial, por insuficiencia de chapuceros historiadores. Cervantes es consciente de que los nombres, y en general el hablar, se interponen entre el hombre y la realidad como filtro deformador atento a hacer valer la representación por lo representado, pero lo real preexiste a lo comunicado en el acto de hablar, el cual carece de legitimidad moral si trata de sustituir su papel vicario por el de generador de realidades. No deja de sorprender que las secuelas del ensayo de Spitzer hayan tomado el camino equivocado de tratar de definir al personaje por sus identificaciones en lugar de explicar el papel del nombre en la constitución de su identidad ${ }^{71}$; algo parecido puede achacarse a las interpretaciones simbólicas, eróticas o carnavalescas del nombre, pues tratan de explicar qué significa sin tener en cuenta su para qué en la estructura del texto.

Cervantes aborda el problema de las diferentes perspectivas en que quiere encerrarse la sustanciación de lo real (en este caso particular, la identidad de su personaje) y lo aborda como actitud interesada de quienes confunden su propio punto de vista con la realidad misma; lejos de hacerla suya, rechaza esa actitud. Esa es, en esencia, la crítica que Cervantes hace a la novela caballeresca: la de ser una falsificación, o, lo que es lo mismo, la de hacerse pasar por representación verdadera de realidades inexistentes ${ }^{72}$. El tratamiento narrativo

71. Graciela C. LAmana de Lasa, por ejemplo, iguala "la oscilación de los nombres" con "la oscilación de la realidad" y sostiene que "la magia del nombre don Quijote de la Mancha crea y articula una realidad nueva" ("Enfoque estilístico de la nominación...", p. 147)

72. No se puede abordar aquí el problema de la legitimidad de la ficción, nunca cuestionada por Cervantes. Con las palabras del cuerpo de este trabajo me refiero al hecho de que la novela de caballerías, utilizando recursos como el del manuscrito supuestamente transcrito, trate de justificarse como relato histórico y no como creación ficticia. El problema es del lector que cae en la trampa de acep- 
que reciben los nombres del protagonista le sirve para mostrar su postura ante un problema que, en el fondo, no es otro que el de la verdad.

Pero esa crítica no se concreta únicamente en aspectos más o menos formales, como la variación onomástica; esta es, a su vez, concreción de una de las múltiples posibilidades de encarnación del problema de fondo: el concepto de uno mismo, la verdad de la propia identidad. El nombre de don Quijote es tan poco caballeresco como su heroicidad. Juan Bautista Avalle-Arce se ha fijado en que Cervantes pone escrupuloso cuidado en eliminar de su personaje cuanto pudiera asimilarlo a los caballeros andantes literarios: no permite conocer los detalles de su nacimiento, su patria ni sus padres y hasta ridiculiza su nombre ${ }^{73}$. El héroe literario (y el caballero andante de novela lo es) cumple un destino para el que había sido convocado desde antes de nacer; su historia es la de la realización de unos designios que fatalmente (es decir, de manera necesaria) se cumplen en él. El héroe afronta el momento decisivo de su vida y asume el destino para el que se siente llamado; como Javier Gomá aprecia en el caso de Aquiles, "se esfuerza por realizar su ser en el devenir" supone aceptarse en la proyección pública de su ser personal. Las empresas de este tipo de héroe, reconocible en sus actos externos, están llamadas al éxito y a la gloria que ensalza el historiador o canta el poeta.

El héroe cervantino, sin embargo, es de muy distinta naturaleza; su obvio fracaso como caballero andante no empaña su faceta heroica, en el sentido que da a lo heroico Ortega y Gasset: "El carácter de lo heroico estriba en la voluntad de ser lo que aún no se es"75. Enfrentado a fabulosas criaturas y fantasiosas empresas de novela, el caballero andante sale siempre victorioso, pero don Quijote es caballero andante enfrentado a la vida y poco puede hacer contra criaturas tan aparentemente inofensivas (tan despiadadas en realidad) como venteros, arrieros, cuadrilleros, cortesanos y todo tipo de vestiglos que pueblan la vida cotidiana. La tarea de Aquiles o la de Amadís consiste en someter un mundo caótico a un ordenado cosmos y ambas son realizables, y realizadas, dentro del ámbito de lo fantástico; creer que es realizable en el de lo real es el error de don Quijote, de ahí su fracaso.

Pero el personaje cervantino no se limita a ser don Quijote; don Quijote, aun cuando llena casi por completo la narración, solo es una parte de la identidad del protagonista y la tarea de este, al final, se revela otra: la de enfrentarse a la hazaña suprema de vivir con dignidad, lo cual se resume en haber sabido elegir el cauce de su autenticidad y mantenerlo incólume. No repara Gomá en que la gloria de Aquiles precisa de la pluma de Homero, como la de

tarlo como testimonio histórico; pero no es menos cierto que el género proporciona ocasión para la confusión.

73. Juan Bautista Avalle-Arce, Don Quijote como forma de vida, Valencia, Castalia/Fundación Juan March, 1976; capítulo III: "El nacimiento de un héroe".

74. JaVIER Gomá LANZÓn, "Aquiles en el gineceo. Las dos alternativas del dilema del hombre: dios vs. ciudadano”, Claves de Razón Práctica, núm. 151, mayo de 2005, pp. 16-22.

75. José Ortega y Gasset, Meditaciones del Quijote, Madrid, Revista de Occidente, 1975, 9. ${ }^{a}$ edición, p. 141. 
Amadís precisa la de Rodríguez de Montalvo: es decir, esta idea de heroísmo necesita el reconocimiento de otro y lo necesita tanto, por lo menos, como las hazañas mismas del héroe. El heroísmo cervantino tiene su sede en la intimidad y no precisa el concurso de fanfarria ni trompetería. Enfrentados a la vida, el héroe épico o el caballero andante no pasan de un estadio de la conciencia de sí mismos semejante al del hidalgo del arranque de la novela cervantina, del que solo se diferencian por su éxito, pero, en el fondo, son lo que son porque otros los reconocen de esa manera. La identidad del héroe épico y del caballero andante están tan cumplidamente definidas como sus respectivas tareas están acabadas; la del héroe de Cervantes está en permanente desarrollo porque tiende a una meta -la del deber ser- inalcanzable por definición: su éxito o su fracaso no vienen dados por la realización, sino por la lealtad a uno mismo o por la dimisión, respectivamente.

El significado de los nombres, entendido como representación semántica, resulta muy secundario, si no indiferente, en el Quijote; lo importante es lo que Cervantes hace con ellos: dotarlos de un sentido que trasciende los valores semánticos convencionales, si es que en los nombres del personaje central pueden apreciarse tales valores semánticos. Los nombres se pliegan al fluir del personaje y no a la inversa; la construcción de don Quijote a partir del hidalgo y la de Alonso Quijano como superación de ambos, la pugna por mantener claramente delimitada su individualidad y la conquista de la autenticidad es lo que les da el valor que tienen en la novela. Poco importa que Cervantes haya inventado los nombres o los haya tomado de sus experiencias inmediatas ${ }^{76}$, lo esencial es que su capacidad creadora los transforma en instrumento apto para conformar su concepción de la vida.

76. Luis Astrana Marín (Vida ejemplar y heroica de Miguel de Cervantes Saavedra, Madrid, Instituto Editorial Reus, 1953, tomo IV, p. 46), siguiendo a RoDRíGUEZ MARíN, postula la creación del personaje cervantino sobre un modelo vivo: "El modelo de Don Quijote fue fray Alonso Quijada. [...] En el propio hogar de Cervantes, por haber sido fray Alonso Quijada contemporáneo de doña Catalina de Vozmediano, la abuela de su esposa, pudo conocer, ya por su suegra, ya por el clérigo Juan de Palacios, ya por otros familiares, vecinos o por los mismos Quijadas, algunas particularidades de aquella persona”. En esa misma línea, RAFAEL SÁNCHEZ MARIÑo ("Un Alonso Quijano de carne y hueso", Anales Cervantinos, IX, 1961-1962, pp. 257-258) descubrió tres documentos en los archivos de Simancas y de protocolos de Madrid, fechados en 1604 y 1605, en los que se menciona un Alonso Quijano, de Valladolid, y postula que Cervantes pudo conocerlo y tomar de él el nombre de su personaje en la segunda parte. Actualmente apenas se sostiene la hipótesis de que Cervantes hubiese elaborado su personaje tomando como modelo a un Alonso Quijada, de Esquivias, de quien pudo recibir noticia por la familia de Catalina Salazar, o cualquier persona real de nombre similar al del hidalgo cervantino, pues aunque tal cosa pudiera haber sucedido, la obra artística no es un mero reflejo de la realidad. Si es verdad que la obra literaria está relacionada con la experiencia de vida de su creador, no menos verdad es que la creación va más allá de lo vivido, deformándolo, transformándolo y fundiéndolo con lo imaginario, de modo que lo puramente episódico no pasaría, en cualquier caso, de ser materia en estado bruto, difícilmente reconocible en el acabado de la elaboración artística. La hipótesis del modelo vivo conduce a un callejón sin salida poco relevante para el sentido de la obra literaria. 


\title{
Resumen
}

El protagonista del Quijote recibe varios nombres en etapas bien diferenciadas. La incertidumbre sobre el nombre del hidalgo del primer capítulo, la fijeza de don Quijote de la Mancha (en contraste con la inestabilidad de los apelativos Caballero de la Triste figura y $\mathrm{Ca}$ ballero de los Leones) y la autenticidad de Alonso Quijano en el capítulo final constituyen sucesivas maneras de nombrar al personaje. Esos nombres están relacionados con la conciencia que tiene de sí mismo y reflejan una sola identidad, mudable en el desarrollo de su hacerse a sí mismo. El sentido de cada uno de esos nombres está determinado por el hecho de oponerse a los otros nombres y por reflejar distintos matices de la identidad del protagonista del Quijote, lo cual le sirve a Cervantes para criticar las formas y el fondo de la novela caballeresca.

Palabras clave: Nombre propio, nombre apelativo, identidad, parodia.

\begin{abstract}
The main character of Don Quijote de la Mancha receives several names in well differentiated stages. The uncertainty on the name of the hidalgo in the first chapter, the certain name of don Quijote (in contrast with instability of two appelatives; Caballero de la Triste Figura and Caballero de los Leones) and his authentic name (Alonso Quijano), revealed in the final chapter, succesive ways to referring him. Those names are related with a variable awareness of self during story. The sense of each name is determinate by opposition to the other names and by different nuances of personal identity. Cervantes uses the diversity of names and his identity concept for criticize the forms and contents of chivalric romances.
\end{abstract}

Key words: Name, appellation, identity, parody. 